\title{
Temporal variations in the carbonate system in the upper layer at the SEATS station
}

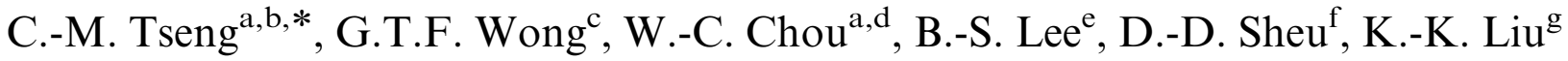 \\ ${ }^{a}$ National Center for Ocean Research, National Taiwan University, Taipei 106, Taiwan, ROC \\ ${ }^{\mathrm{b}}$ Institute of Oceanography, National Taiwan University, P.O. Box 23-13, Taipei 106, Taiwan, ROC \\ ${ }^{\mathrm{c}}$ Research Center for Environmental Changes, Academia Sinica, Nankang, Taipei 115, Taiwan, ROC \\ ${ }^{\mathrm{d}}$ Institute of Marine Environmental Chemistry and Ecology, National Taiwan Ocean University, Keelung 202, Taiwan, ROC \\ ${ }^{\mathrm{e}}$ Department of Biotechnology, ChungChou Institute of Technology, Yuanlin, Changhua 510, Taiwan, ROC \\ ${ }_{\mathrm{f}}^{\mathrm{f}}$ Institute of Marine Geology and Chemistry, National Sun Yat-Sen University, Kaohsiung 804, Taiwan, ROC \\ ${ }^{\mathrm{g}}$ Institute of Hydrological Sciences, National Central University, Jungli 320, Taiwan, ROC
}

Accepted 10 May 2007

Available online 20 July 2007

\begin{abstract}
The distributions of total carbon dioxide $\left(\mathrm{TCO}_{2}\right)$ and alkalinity (TA) in the upper layer at the SouthEast Asian Timeseries Study (SEATS) station at $18^{\circ} \mathrm{N}$, and $116^{\circ} \mathrm{E}$ in the northern South China Sea (SCS) were determined on 19 cruises between September 1999 and October 2003. The variations in the concentrations of $\mathrm{TCO}_{2}$ and TA in the mixed layer, which ranged between 1860 and $1920 \mu \mathrm{mol} \mathrm{kg}{ }^{-1}$, and 2170 and $2230 \mu \mathrm{mol} \mathrm{kg}^{-1}$, respectively, followed a distinct intraannual pattern like that of salinity. The maximum concentrations were found in the winter as enhanced vertical mixing brought the subsurface Tropical Water, which was more saline and elevated in TA and $\mathrm{TCO}_{2}$, to the mixed layer. There was an even more well-defined and consistent intra-annual pattern in the variations in the associated fugacity of $\mathrm{CO}_{2}$, $\mathrm{fCO}_{2}$, that fluctuated between 340 and $400 \mu \mathrm{atm}$. However, the variations followed the temporal pattern in temperature more closely than that in salinity as $\mathrm{fCO}_{2}$ rose systematically towards a maximum in the summer and then fell progressively to a minimum in the winter. The intra-annual variations in TA could be accounted for largely by the variations in salinity. Once TA was normalized to the average salinity of 33.5 in the mixed layer, the variations in the resulting NTA were only slightly larger than the analytical uncertainty and they did not follow a consistent intra-annual pattern. On the other hand, consistent intra-annual variations remained evident in $\mathrm{NTCO}_{2}, \mathrm{TCO}_{2}$ normalized to a salinity of 33.5 , and $\mathrm{NfCO}_{2}, \mathrm{fCO}_{2}$ normalized to the average temperature of $27.6{ }^{\circ} \mathrm{C}$ in the mixed layer. In fact, the patterns in the intra-annual variations in $\mathrm{NTCO}_{2}$ and $\mathrm{NfCO}_{2}$ mimicked each other closely. From the late winter through the summer (February-August), the uptake of carbon in primary production and the evasion of $\mathrm{CO}_{2}$ to the atmosphere led to a drawdown in $\mathrm{NTCO}_{2}$ and a decrease in $\mathrm{NfCO}_{2}$. From the late summer to the early winter (August-December), variations in $\mathrm{NTCO}_{2}$ and $\mathrm{NfCO}_{2}$ were small. The variations in $\mathrm{TCO}_{2}$ and $\mathrm{fCO}_{2}$ could be explained largely by changes in salinity and temperature, respectively. In the winter (December-February), both $\mathrm{NTCO}_{2}$ and $\mathrm{NfCO}_{2}$ were at a maximum, indicating that the effects of the net invasion of atmospheric $\mathrm{CO}_{2}$ to the SCS and the enhanced vertical mixing of the surface waters with the subsurface Tropical Water dominated over the effect from the higher primary production during this season. Atmospheric fCO $\mathrm{fl}_{2}$ was less than $\mathrm{fCO}_{2}$ in the mixed layer from April through October and exceeded the latter from November through March. For the year as a whole, there was a net invasion of $\mathrm{CO}_{2}$ of $0.02 \mathrm{~mol} \mathrm{C} \mathrm{m}^{-2} \mathrm{yr}^{-1}$, a value that was indistinguishable from zero,
\end{abstract}

\footnotetext{
*Corresponding author. Institute of Oceanography, National Taiwan University, P.O. Box 23-13, 1, Section 4, Roosevelt Road, Taipei 106-17, Taiwan, Republic of China. Tel.: + 886223636450x309; fax: +886223644049.

E-mail address: cmtseng99@ntu.edu.tw (C.-M. Tseng).
} 
indicating that the northern SCS was neither a significant source nor a significant sink of atmospheric $\mathrm{CO}_{2}$. Inter-annually, there were indications that $\mathrm{NTCO}_{2}$ and $\mathrm{fCO}_{2}$ in the mixed layer were increasing with time at rates of $\sim 1.5 \mu \mathrm{mol} \mathrm{kg}^{-1} \mathrm{yr}^{-1}$

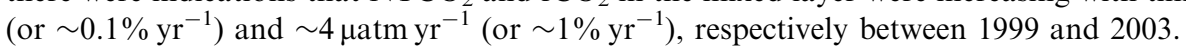

(C) 2007 Elsevier Ltd. All rights reserved.

Keywords: Carbon dioxide; Air-sea exchange; Time-series; South China Sea; SEATS

\section{Introduction}

The accelerated rise in the concentration of atmospheric $\mathrm{CO}_{2}$ since the industrial revolution is one of the best documented incidents of global environmental change as a result of human activities, and it is widely believed that this change in the atmospheric composition may bring significant and even devastating socio-economic impacts (IPCC, 2001). It has long been postulated that the response of the ocean to changes in atmospheric $\mathrm{CO}_{2}$ can play a crucial role in mediating the resulting changes in atmospheric $\mathrm{CO}_{2}$ (Houghton et al., 2001). Furthermore, as the ocean responds to this external forcing, its own chemistry and ecology also may be altered (Feely et al., 2004; Royal Society, 2005). Thus, a firm grasp on the oceanic response to changes in atmospheric $\mathrm{CO}_{2}$ is needed for understanding the rise in atmospheric $\mathrm{CO}_{2}$ as well as the impact of this environmental change on the ocean.

Time-series stations have been established to record the response of the ocean to the rising atmospheric $\mathrm{CO}_{2}$ through direct observations. The longest records that have been compiled to date are those at the HOT, Hawaii Ocean Time-series, and the BATS, Bermuda Atlantic Time-series Study, stations that were established in 1988. At these two sites, the records indicate that as the concentration of atmospheric carbon dioxide increased at the rate of about $0.4 \% \mathrm{yr}^{-1}$, concomitantly, the concentration of total carbon dioxide $\left(\mathrm{TCO}_{2}\right)$ in the surface waters also increased at a rate of $1-2 \mu \mathrm{mol} \mathrm{kg} \mathrm{yr}^{-1}$ (Winn et al., 1998; Bates et al., 1996, 1998, 2001). The SouthEast Asian Time-series Study (SEATS) station was established in the northern South China Sea in 1999. Measuring the distributions of the carbonate species at the station has been part of the core analytical program of the study since its inception. While the data from the SEATS site will augment those from the HOT and BATS sites in documenting the global response in the oceanic carbonate system to the rising atmospheric $\mathrm{CO}_{2}$, the SEATS site also represents a fundamentally different type of marine sub-environment (Karl et al.,
2003). While the HOT site is located in the North Pacific Subtropical Gyre $\left(22^{\circ} 45^{\prime} \mathrm{N}, 158^{\circ} 00^{\prime} \mathrm{W}\right)$ and the BATS site is located in the temperate north Atlantic $\left(31^{\circ} 50^{\prime} \mathrm{N}, 64^{\circ} 10^{\prime} \mathrm{W}\right)$, the SEATS site $\left(18^{\circ} \mathrm{N}\right.$, $\left.116^{\circ} \mathrm{E}\right)$ is located in the tropics in a marginal sea. As environmental conditions change with latitude and with proximity to land, the forcing on the carbonate system at the SEATS site is expected to be different from that at the HOT and BATS site. Here, we report the behavior of the carbonate system in the upper layer at the SEATS site from 1999 to 2003.

\section{Experimental}

\subsection{Study area}

The South China Sea (SCS) (Fig. 1) is one of the largest semi-enclosed marginal seas in the world. It covers an area of $3.5 \times 10^{6} \mathrm{~km}^{2}$ with an average depth of $1350 \mathrm{~m}$ although its maximum depth can reach $5000 \mathrm{~m}$. The main basin of the SCS extends from about $22^{\circ} \mathrm{N}$ along the coasts of southern China to about the equator along the Sunda Shelf north of Borneo and from about $108^{\circ} \mathrm{E}$ along the coast of the Indo-Chinese Peninsula to $120^{\circ} \mathrm{E}$ along the western coast of the Philippine islands. Thus, almost the entire sea lies within the tropical zone. The SEATS station is located in the tropical northern SCS at $18^{\circ} \mathrm{N}, 116^{\circ} \mathrm{E}$ in about $3800 \mathrm{~m}$ of water. The surface water is warm year round. The seasonal variations in sea-surface temperature are small and the upper water column is well stratified at all times (Wong et al., 2002; Tseng et al., 2005) so that the effect of the solubility pump for the exchange of carbon dioxide between the SCS and the atmosphere is not expected to be particularly effective.

In contrast, several sources of allochthonous nutrients may reach the SCS to fuel the biological pump. The Mekong River and the Pearl River are major rivers in the world. Both of them empty into the SCS from the west and provide significant terrestrial inputs of nutrients to the SCS. Terrestrial material also can reach the SCS in exchanges 


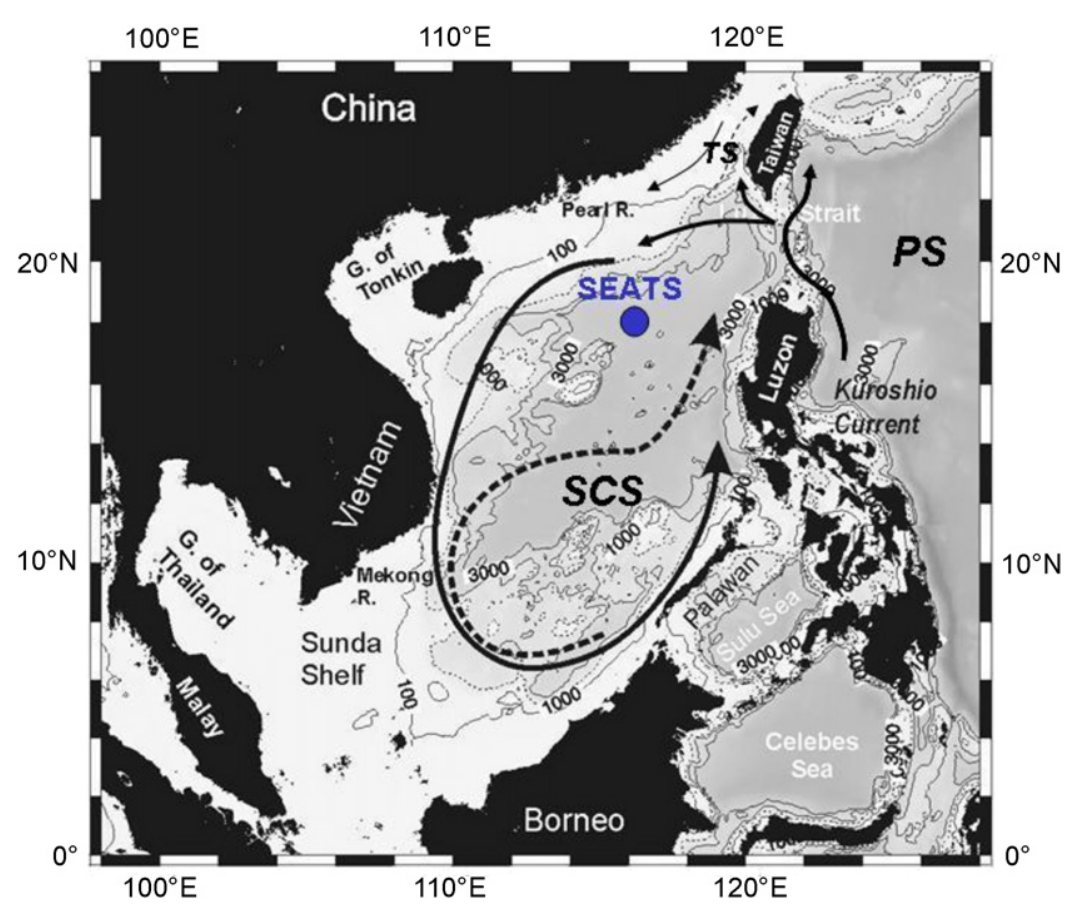

Fig. 1. The location of the SouthEast Asian Time-series Study (SEATS) station in the northern South China Sea. Solid line- cyclonic gyre in the winter; Dashed line - anti-cyclonic gyre. The flow path of the Kuroshio and its intrusion into the South China Sea are also shown. TS - Taiwan Strait; PS - Philippine Sea; SCS - South China Sea.

between the SCS and the East China Sea through the Taiwan Strait. Nonetheless, since the SEATS station is located in the deep basin in the northern $\mathrm{SCS}$, it is relatively far removed from the coasts of China and the Indo-Chinese Peninsula and it is also separated from the shelf by the along shore boundary currents (Fig. 1). As a result, the contribution of the terrestrial nutrients to the biological pump at the SEATS site may be relatively minor. In fact, the surface water at the SEATS station is oligotrophic in most of the year (Tseng et al., 2005; Wong et al., 2002, 2007). Exchange between the surface and the deep water is another possible allochthonous source of nutrients to the euphotic zone at the SEATS station. The primary exchange between the SCS and the open ocean occurs through the Luzon Strait, which connects the SCS with the Philippine Sea in the northwestern Pacific Ocean. The large inflow of deep water from the Philippine Sea leads to a basin-scale upwelling in the SCS (Chao et al., 1996a,b; Liu et al., 2002) and this results in a shallow thermocline, nitricline and mixed-layer depth (MLD). The depth at the top of the nutricline (TND) is found between 40 and $70 \mathrm{~m}$ while the MLD is less than $50 \mathrm{~m}$ during most of the year (Tseng et al., 2005). Since the SCS is situated between the western Pacific warm pool and the Tibetan Plateau, its surface circulation is strongly influenced by the resulting seasonal monsoons (Chao et al., 1996a, b): a weaker southwest monsoon in the summer and a stronger northeast monsoon in the winter. The combined forcing of surface cooling and the strong northeast monsoon acting on the shallow nutricline is sufficient to make the nutrients in the upper nutricline available for supporting a regular pattern of higher primary production in the winter (Tseng et al., 2005). Superimposed on this general seasonal trend are intermittent events that may lead to high primary production. More than 10 tropical cyclones-tropical depressions traverse the SCS annually. Lin et al. (2003) reported that such events can lead to dramatically higher primary production, as the nutrients in the upper nutricline are mixed into the surface waters. Nitrogen fixation is yet another possible component of the biological pump in the northern SCS. The environmental conditions in the northern SCS are conducive to (Wong et al., 2002, 2007; Lin et al., 2007) and the distributions of the nutrients at the SEATS site are consistent with its 
occurrence (Wong et al., 2002, 2007). In fact, the occurrence of nitrogen fixation in the SCS has been reported periodically (Capone et al., 1997).

\subsection{Sampling program}

The SEATS station was occupied 19 times between September 1999 and October 2003 in approximately seasonal intervals aboard $\mathrm{R} / \mathrm{V}$ Ocean Researcher III (OR3 cruises 561 (September 17-22, 1999), 585 (November 22-26, 1999), 600 (January 17-18, 2000), 607 (March 12-17, 2000), 629 (May 23-26, 2000), 644 (July 25-27, 2000), 657 (October 16-21, 2000), 682 (February 27-March 4, 2001), 716 (June 27-July 1, 2001), 729 (October 2-7, 2001) and 794 (July 1-3, 2002)) and R/V Ocean Researcher I (OR1-cruises 632 (December 5-11, 2001), 639 (March 19-April 2, 2002), 656 (September 3-4, 2002), 664 (November 11-13, 2002), 673 (January 20-21, 2003), 674 (March 5-6, 2003), 690 (August 7-8, 2003) and 696 (October 4-5, 2003)). During each occupation of the station, the distributions of temperature and salinity were recorded repeatedly at 3-h intervals for $36 \mathrm{~h}$ whenever possible with a SeaBird model SBE9/11 conductivity-temperaturedepth (CTD) recorder. Photosynthetically available radiation (PAR) and in situ fluorescence were recorded with a Biospherical model QSP-200L quantum scalar irradiance sensor and a Chelsea AQUATRACKA III fluorometer. Discrete samples were collected at approximately 25 depths to at least $2400 \mathrm{~m}$ with GO-FLO bottles mounted onto a Rosette sampling assembly (General Oceanic). Sub-samples were then collected for the determination of salinity, phosphate, silicate, chlorophyll $a$ (chl-a), total $\mathrm{CO}_{2}\left(\mathrm{TCO}_{2}\right)$ and total alkalinity (TA).

In the upper layer in the top $200 \mathrm{~m}$ of the water column, samples were collected at 10 depths for the determinations of $\mathrm{TCO}_{2}$ and TA. Replicate subsamples were obtained at three depths. The samples were poisoned with $50 \mu \mathrm{l}$ of a saturated $\mathrm{HgCl}_{2}$ solution immediately after sampling and were stored at $4{ }^{\circ} \mathrm{C}$ in the dark in BOD bottles until they were analyzed in a shore-based laboratory (DOE, 1994).

The fugacity of $\mathrm{CO}_{2}\left(\mathrm{fCO}_{2}\right)$ in the surface seawater and in the atmosphere was measured simultaneously during three cruises (OR1 cruises 632, 690 and 696) by using an underway system (Wanninkhof and Thoning, 1993). In this system, $\mathrm{CO}_{2}$ in the air or in a carrier gas that had come into equilibrium with a sample of surface seawater was analyzed with a non-dispersive infrared detection system (LI-COR $\mathrm{CO}_{2}$ detector). The system was standardized against a standard $\mathrm{CO}_{2}$ gas obtained from the National Oceanic and Atmospheric Administration. The precision in the determination of $\mathrm{fCO}_{2}$ with this system was less than $\pm 0.5 \mu \mathrm{atm}$.

\subsection{Determination of $\mathrm{TCO}_{2}$ and $\mathrm{TA}$}

$\mathrm{TCO}_{2}$ and TA were determined according to the standard procedures recommended by the Department of Energy (Department of Energy (DOE), 1994). $\mathrm{TCO}_{2}$ was analyzed by using a single operator multiparameter metabolic analyzer (SOMMA) system coupled to a $\mathrm{CO}_{2}$ coulometric detector (Model 5011, UIC Coulometrics Inc.). In this method, the sample was acidified with phosphoric acid in order to convert all the inorganic species of dissolved carbon to $\mathrm{CO}_{2}$, which was then extracted from the sample and then determined with the coulometeric detector (Johnson et al., 1993).

TA was determined by a potentiometric titration (Bradshaw et al., 1981; Millero et al., 1993; DOE, $1994)$ of the sample $(\sim 150 \mathrm{ml})$ in an open titration cell at a constant temperature of $25 \pm 0.05^{\circ} \mathrm{C}$ to the bicarbonate end point with hydrochloric acid in an autoburette (Metrohm 665 Dosimat) by using a Radiometer $\mathrm{pH}$ meter (pH M-85) and a GK 2041C combination electrode. The titrant $(0.1 \mathrm{~N} \mathrm{HCl})$ was prepared in a $\mathrm{NaCl}$ solution with an ionic strength similar to that of seawater $\left(0.68 \mathrm{~mol} \mathrm{~kg}{ }^{-1}\right)$. Titration data past the bicarbonate end point $(\sim \mathrm{pH} 4.5)$ were used to calculate TA, which was defined by a proton condition (Dickson, 1981, 1992; Butler, 1992). TA is reported here in $\mu \mathrm{mol} \mathrm{kg}{ }^{-1}$ rather than in $\mu$ eq $\mathrm{kg}^{-1}$, consistent with the usage in the Department of Energy Handbook of Methods (DOE, 1994).

The analytical precision and accuracy in the determination of $\mathrm{TCO}_{2}$ and TA were assessed by using three approaches. First, during each cruise, three deep (2000-3500 m) water samples were analyzed routinely at least in replicates. The $1 \sigma$ precisions were typically $\pm 1 \mu \mathrm{mol} \mathrm{kg}{ }^{-1}$ or $<0.1 \%$ in $\mathrm{TCO}_{2}$ and $\pm 2 \mu \mathrm{mol} \mathrm{kg}^{-1}$ or $\pm 0.1 \%$ in TA. Secondly, the analytical precisions were estimated from the variations in $\mathrm{TCO}_{2}$ and TA over time at a specified density surface in the deep water, where the composition of the water was expected to be invariant with time. At a $\sigma_{\theta}$ of $27.63 \pm 0.01(2500 \pm 200 \mathrm{~m})$, the $1 \sigma$ variations were $\pm 1.9 \mu \mathrm{mol} \mathrm{kg}^{-1}$ in $\mathrm{TCO}_{2}$ over 18 cruises and $\pm 2.4 \mu \mathrm{mol} \mathrm{kg} \mathrm{k}^{-1}$ in TA over 17 cruises between 1999 and 2003 (Chou et al., 2007). Thirdly, samples of 
Seawater Certified Reference Material (CRM) were obtained from A.G. Dickson (Scripps Institution of Oceanography) and were analyzed regularly as part of the overall analytical program of the samples collected from the SEATS site. The certified value and the value obtained in this laboratory for $\mathrm{TCO}_{2}$ were $2030.6 \pm 0.8$ and $2030.1 \pm 0.9(n=25) \mu \mathrm{mol} \mathrm{kg}^{-1}$ for CRM batch 44, and 1994.7 \pm 0.9 and $1994.0 \pm 0.9$ $(n=25) \mu \mathrm{mol} \mathrm{kg}^{-1}$ for CRM batch 45 . For TA, they were $2256 \pm 0.8$ and $2254 \pm 2.0(n=25) \mu \mathrm{mol} \mathrm{kg}^{-1}$ for CRM batch 44 , and $2214.7 \pm 1.2$ and $2214.0 \pm 1.0$ $(n=25) \mu \mathrm{mol} \mathrm{kg}{ }^{-1}$ for CRM batch 45 . Thus, both the precision and accuracy in the determinations of $\mathrm{TCO}_{2}$ and TA in this laboratory were similar to the internationally accepted level of $\pm 1 \mu \mathrm{mol} \mathrm{kg}{ }^{-1}$ (SCOR, 1985).

\subsection{Calculation of the fugacity of $\mathrm{CO}_{2}$}

The fugacity of $\mathrm{CO}_{2}\left(\mathrm{fCO}_{2}\right)$ was calculated from temperature, salinity, and the concentrations of $\mathrm{TCO}_{2}$, TA, phosphate and silicate in the sample. The calculation was carried out by using the program of Lewis and Wallace (1998), in which the apparent dissociation constants of carbonic acid as reported by Mehrbach et al. (1973) and refitted by Dickson and Millero (1987) were used. The associated uncertainty in the estimated $\mathrm{fCO}_{2}$ was less than $\pm 5 \mu \mathrm{atm}$, when the analytical setup for the determination of the concentrations of $\mathrm{TCO}_{2}$ and TA had been calibrated by using Seawater Certified Reference Material. Values of $\mathrm{fCO}_{2}$ estimated from $\mathrm{TCO}_{2}$ and TA agreed with those determined by using the underway system to $\pm 4 \mu$ atm or $\sim 1 \%$.

\subsection{Calculation of the air-sea exchange flux of $\mathrm{CO}_{2}$ at the SEATS station}

As a first approximation, the net air-sea exchange flux of $\mathrm{CO}_{2}$ at the SEATS station during a particular cruise, $F$, was estimated by applying the stagnant film model according to the equation (Liss and Slater, 1974; Broecker and Peng, 1982):

$F=k L \Delta \mathrm{fCO}_{2}$ and

$\Delta \mathrm{fCO}_{2}=\left(\mathrm{fCO}_{2 \mathrm{w}}-\mathrm{fCO}_{2 \mathrm{a}}\right)$,

where $\mathrm{fCO}_{2 \mathrm{w}}$ is the observed average $\mathrm{fCO}_{2}$ in the mixed layer, $\mathrm{fCO}_{2 \mathrm{a}}$ is the monthly averaged $\mathrm{fCO}_{2}$ in the overlying air, $L$ is the solubility of $\mathrm{CO}_{2}$ $\left(\mathrm{mol} \mathrm{m}^{-3} \mathrm{~atm}^{-1}\right)$, and $k$ is the $\mathrm{CO}_{2}$ gas transfer velocity $\left(\mathrm{m} \mathrm{d}^{-1}\right)$. The $\mathrm{fCO}_{2 \mathrm{a}}$ was estimated from the monthly average $\mathrm{pCO}_{2}$ observed at the Mauna Loa
Observatory (Keeling and Whorf, 2004) during the study period after the vapor pressure had been corrected to the equilibrium value at the surface temperature and salinity found at the SEATS station. The contemporaneously estimated values agreed to within $1 \mu \mathrm{atm}$ with the values measured in three cruises by using the underway $\mathrm{fCO}_{2}$ system. The transfer velocity $k$ was parameterized as a function of the monthly averaged wind speed at $10 \mathrm{~m}$ above the sea surface and the Schmidt number at the observed average salinity and temperature in the mixed layer according to the method of Wanninkhof (1992). The average daily wind speed from 1986 to 2003 at around the location of the SEATS station was obtained from the European Center for Medium-Range Weather Forecasts (ECMWF). Two methods were used for estimating the monthly averaged wind speed from these daily wind speeds. The long-term averaged climatological wind speed was computed as the average wind speed in each month of the year over these 18 years. The short-term monthly wind speed was the average wind speed during the sampling month. The solubility of $\mathrm{CO}_{2}$ was estimated by using the equation of Weiss (1974).

\subsection{Other ancillary data}

Salinity in discrete samples was determined by using an AUTOSAL salinometer (Guildline Model 8400B), which had been calibrated against IAPSO Standard Seawater (Ocean Scientific International Ltd., UK) with a precision of \pm 0.002 . Soluble reactive phosphate (SRP) was determined manually with the standard molybdenum blue method (Strickland and Parsons, 1984) with a precision of $\pm 0.5 \%$. Silicate was determined spectrophotometrically by the silicomolybdenum blue method (Strickland and Parsons, 1984) with a precision of $\pm 1 \%$. The concentration of chl- $a$ in particulate material collected by filtration through glass fiber filters with a nominal pore size of $0.45 \mu \mathrm{m}$ was determined by the standard fluorometric method (Strickland and Parsons, 1984).

\section{Results and discussion}

\subsection{Seasonal cycles in the hydrographic properties in the upper layer}

The distributions of potential temperature and salinity in the top $200 \mathrm{~m}$ of the water column and 
their average values in the mixed layer at the SEATS station between September 1999 and October 2003 are shown in Figs. 2 and 3. The typical season profiles, as represented by the profiles observed during October 2001 and July 2002, are shown in Fig. 4A and B. While seasonal variations in temperature and salinity were minimal at depths below $150 \mathrm{~m}$, a prominent seasonal cycle was clearly evident in the top $50 \mathrm{~m}$ of the water column. The average temperature in the mixed layer rose progressively from a minimum of $24-26^{\circ} \mathrm{C}$ in the winter through the spring to a maximum of $28-31{ }^{\circ} \mathrm{C}$ in the summer before it fell steadily through the fall and reached the minimum again in the winter (Fig. 3A). Both the surface cooling and the strong northeast monsoon promoted vertical mixing in the winter. As a result, the mixed-layer depth (MLD), increased from around $20 \mathrm{~m}$ in the summer to $50-90 \mathrm{~m}$ in the winter (Fig. 3C, Tseng et al., 2005) and the subsurface layer just below the mixed layer $(\sim 70-150 \mathrm{~m})$ was the warmest in the winter (Fig. 4A). The MLD was defined as the surface layer within which the density gradient stayed below $0.05 \sigma_{\theta}$ unit $\mathrm{m}^{-1}$ (Tseng et al., 2005).

Salinity in the mixed layer followed a different seasonal pattern relative to that of temperature (Fig. 2). The highest salinity (33.6-34.0) was found in the winter while the lowest value was found mostly in the spring or the fall (Figs. 3B and 4B). The high salinity in the winter was probably related to the enhanced vertical mixing between the fresher surface water and the saline subsurface Tropical Water, which appeared as the salinity maximum ( 34.6) centered around $150 \mathrm{~m}$ (Fig. 2B), during this
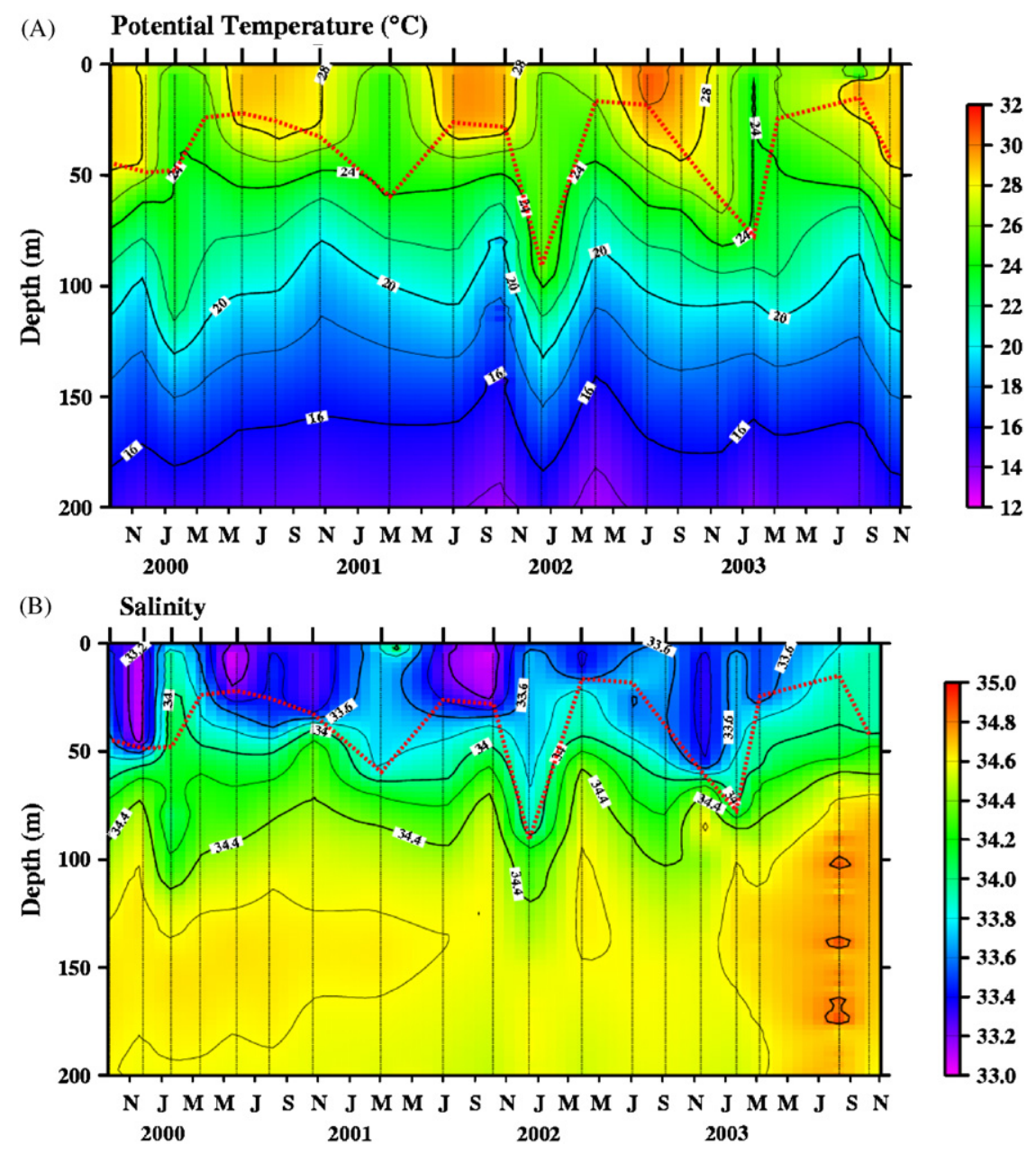

Fig. 2. Variations in (A) potential temperature and (B) salinity in the top $200 \mathrm{~m}$ at the SEATS station between September 1999 and October 2003. Vertical dashed lines with bold marks on the top of the figure denote the time of sampling. The MLD is indicated by the heavy dashed line in (A) and (B). 


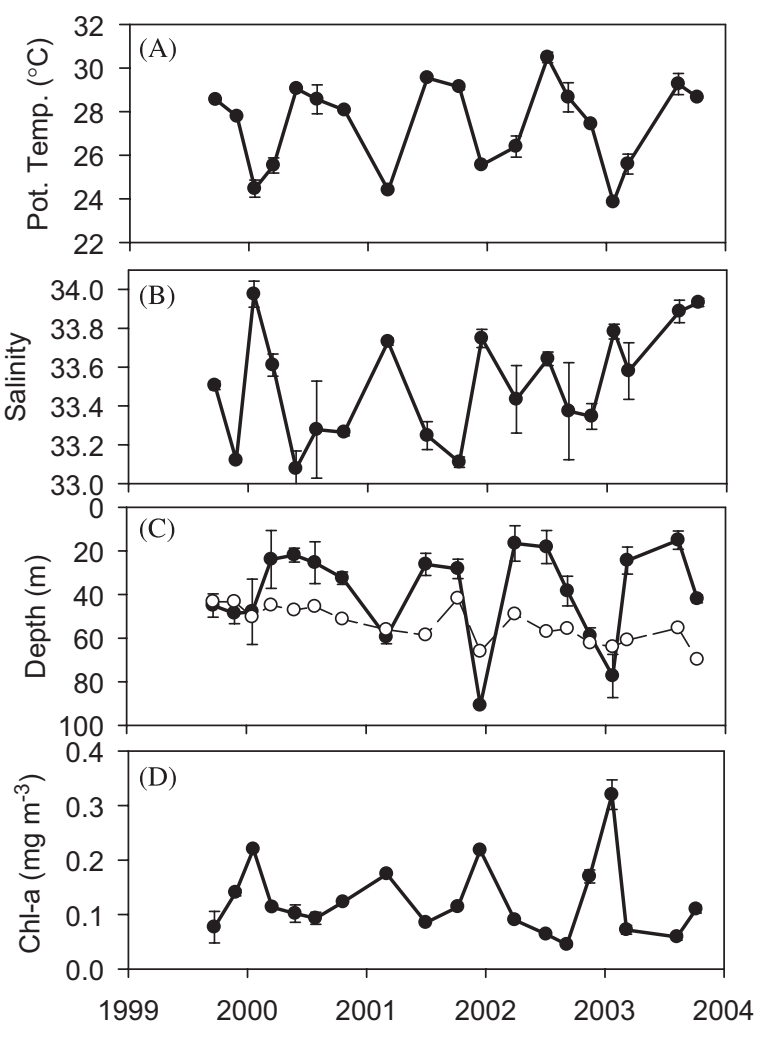

Fig. 3. Variations in (A) the average potential temperature, Pot. Temp., (B) the average salinity, $S$, (C) the mixed-layer depth $(\mathrm{MLD}, \bullet)$, and the depth at the top of the nutricline (TND, $\bigcirc)$, and (D) the average chlorophyll- $a$ in the mixed layer at the SEATS station between September 1999 and October 2003. season. Thus, in the subsurface layer just below the mixed layer, the lowest salinity was found in the winter as mixing with the fresh water in the mixed layer was enhanced (Fig. 4B). The variations in the salinity in the mixed layer in the spring through the fall were likely caused by the seasonal variations in the rates of evaporation and precipitation as the wet season in the SCS occurs between April and October (Hong Kong Observatory Climatological Information Services, 2007) and by the intrusion of the water from the Philippine Sea into the northern SCS.

The depth at the top of the nutricline, TND, was defined here as the $x$-intercept of a plot of nutrient (e.g., SRP) in the upper nutricline against depth (Tseng et al., 2005). It stayed relatively constant through the seasons and through the years between 50 and $70 \mathrm{~m}$ (Fig. 3C) so that it was similar to or even shallower than MLD in the winter. Thus, the enhanced vertical mixing in the winter might have brought bring nutrients to the mixed layer, stimulated primary production (Tseng et al., 2005) and led to the distinct seasonal maximum in the concentration of chl- $a$ in the mixed layer in the winter (Fig. 3D).

\subsection{Seasonal patterns in $\mathrm{TA}, \mathrm{TCO}_{2}$ and $\mathrm{fCO}_{2}$ and their relationship to hydrographic properties}

The variations in $\mathrm{TA}$, and $\mathrm{TCO}_{2}$ in the upper $200 \mathrm{~m}$ of water column and their average values in the mixed layer between September 1999 and

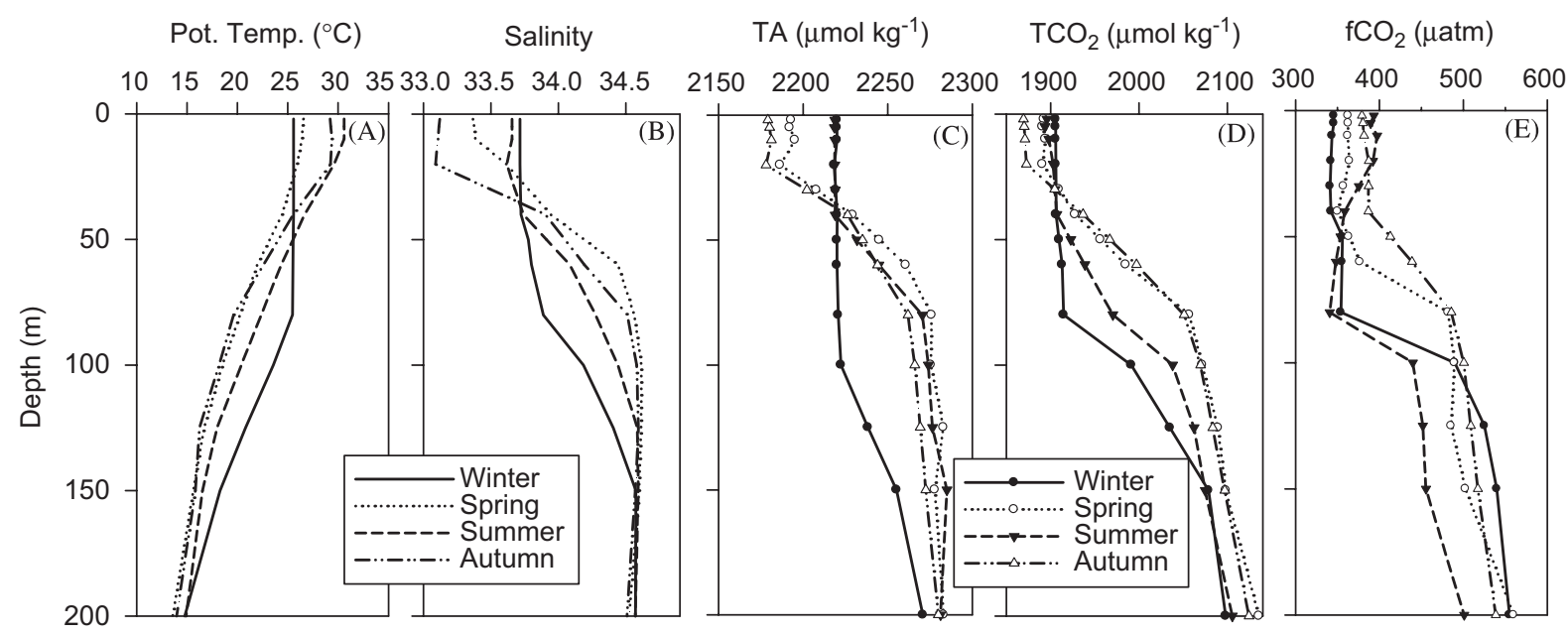

Fig. 4. The vertical distributions of (A) potential temperature, Pot. Temp., (B) salinity, (C) TA, (D) $\mathrm{TCO}_{2}$, and (E) $\mathrm{fCO}_{2}$ in the top $200 \mathrm{~m}$ at the SEATS station in the different seasons from October 2001 to July 2002. Autumn - ORIII 729 (Oct. 2-7 '01); Winter-ORI 632 (Dec. 5-11 '01); Spring-ORI 639 (Mar.19-Apr. 2 '02); Summer-ORIII 794 (July 1-3 '02). 

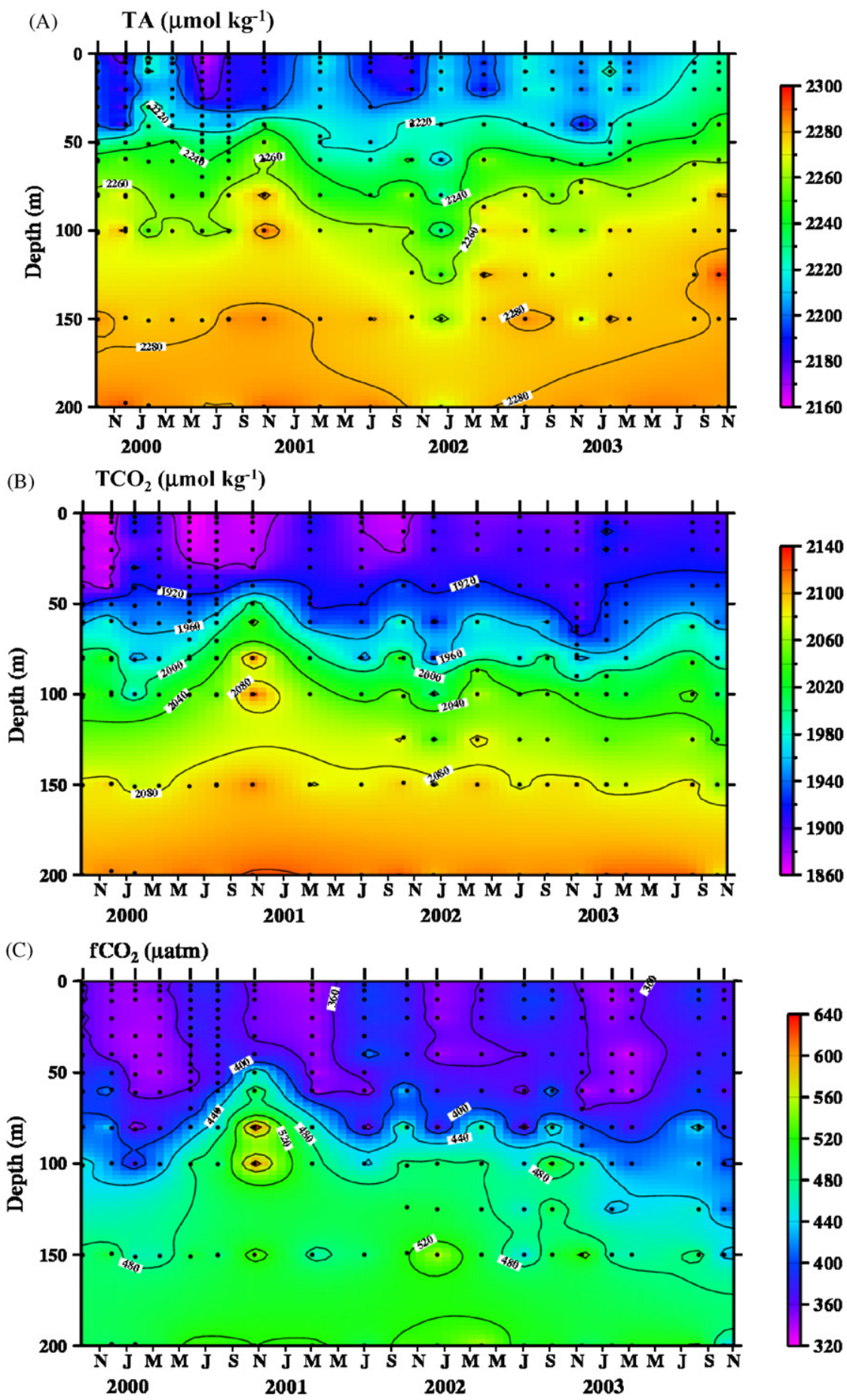

Fig. 5. Variations in (A) TA, (B) $\mathrm{TCO}_{2}$, and (C) $\mathrm{fCO}_{2}$ in the top $200 \mathrm{~m}$ at the SEATS station between September 1999 and October 2003. The times of sampling are indicated by the hash marks along the top boundary of the figure. Data points are indicated as solid dots.

October 2003 are shown in Figs. 5 and 6. Their seasonal profiles from October 2001 to July 2002 are shown in Fig. $4 \mathrm{C}$ and D. TA and $\mathrm{TCO}_{2}$ increased with depth from around 2200 and $1890 \mu \mathrm{mol} \mathrm{kg}^{-1}$ at the sea surface to 2280 and $2080 \mu \mathrm{mol} \mathrm{kg}^{-1}$ below $150 \mathrm{~m}$. As in potential temperature and salinity, large intra-annual variations in $\mathrm{TA}$ and $\mathrm{TCO}_{2}$ were found in the top $50 \mathrm{~m}$ of the water column. The 

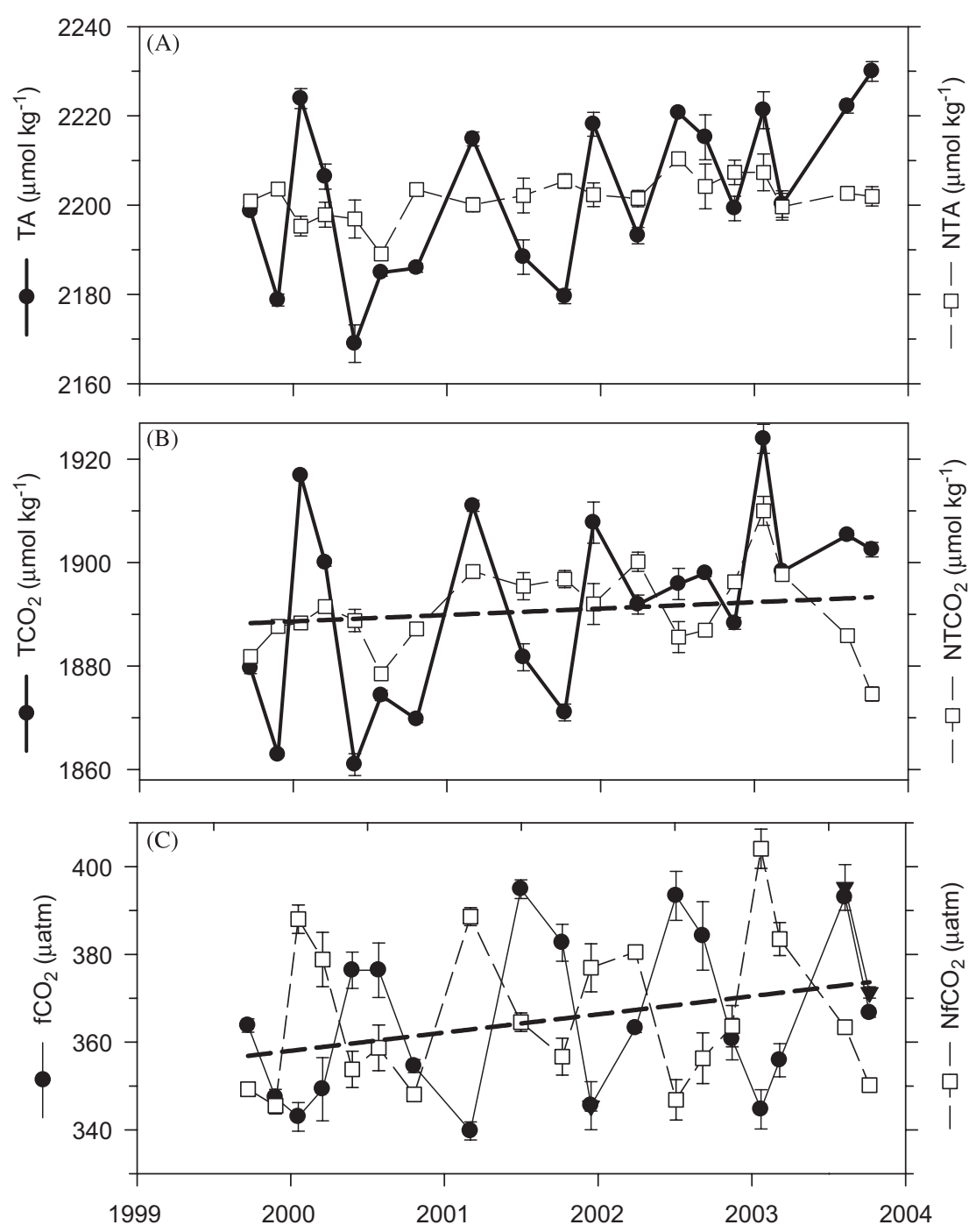

Fig. 6. Variations in the average (A) TA and NTA, (B) $\mathrm{TCO}_{2}$ and $\mathrm{NTCO}_{2}$, and (C) $\mathrm{fCO}_{2}$ and $\mathrm{NfCO}_{2}$ in the mixed layer at the SEATS

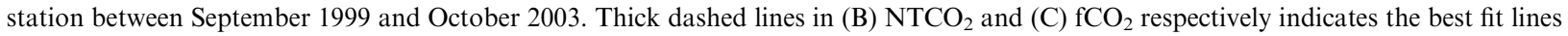
by a linear regression analysis.

seasonal patterns in both TA and $\mathrm{TCO}_{2}$ followed that of salinity closely. In the mixed layer, the highest TA and $\mathrm{TCO}_{2}$ were found in the winter while the lowest values were found mostly in the spring or the fall (Fig. 6). The enhanced vertical mixing in the winter brought the Tropical Water with higher salinity, TA and $\mathrm{TCO}_{2}$ to the mixed layer and this could account for this annual maximum in $\mathrm{TA}$ and $\mathrm{TCO}_{2}$ in the mixed layer and the concomitant annual minimum in TA and $\mathrm{TCO}_{2}$ in the subsurface layer just below the mixed layer (Fig. 4C and D). TA was linearly related to salinity, $S$, from the surface to the core of the Tropical
Water at $150 \mathrm{~m}$ (Fig. 7A) such that

$$
\begin{aligned}
\mathrm{TA} & =65.7( \pm 1.1) \times S-1( \pm 38), \\
r^{2} & =0.95, n=204,
\end{aligned}
$$

where $r$ was the correlation coefficient and $n$ was the number of data points. The numbers in parentheses were the $1 \sigma$ uncertainties in the slope and the intercept. Millero et al. (1998) also found that TA was linearly related to salinity with no significant intercept in the northern and sourthern gyres in the Pacific Ocean. The slope of $65.7 \mu$ mole $\mathrm{kg}^{-1}$ reported here is exactly the same as the value given by 
(A)

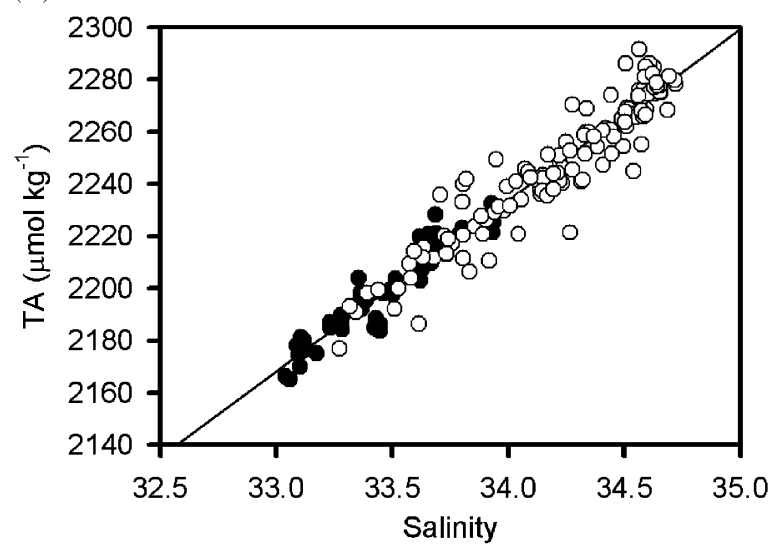

(B)

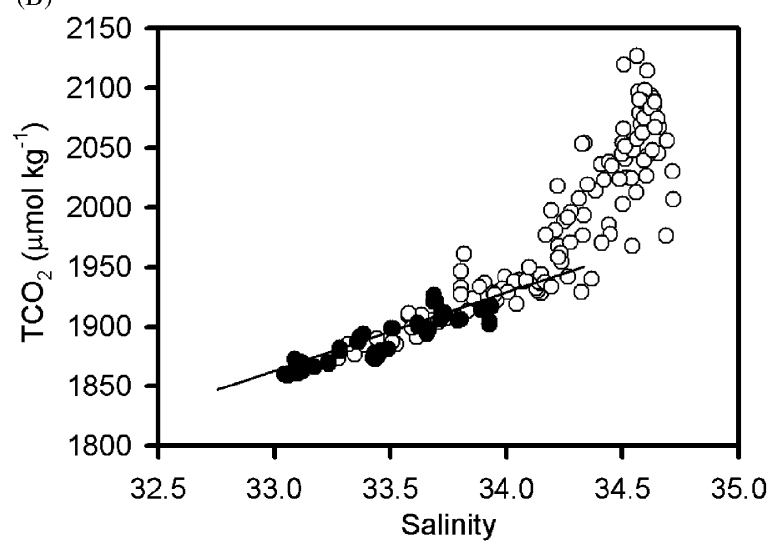

Fig. 7. The relationships between (A) TA and (B) $\mathrm{TCO}_{2}$ and salinity in the top $150 \mathrm{~m}$ at the SEATS station between September 1999 and October 2003. • - in the mixed layer; O_-bottom of the mixed layer to $150 \mathrm{~m}$. The best fit line by a linear regression analysis of all data points is shown in (A) and that of data points from within the mixed layer only is shown in (B).

them since they estimated an average TA of $2300 \mu$ mole $\mathrm{kg}^{-1}$ at a salinity of 35 , so that the slope would be $2300 / 35$ or 65.7 . These affirm the general recognition that changes in TA in the upper layer in the warm open oceans are driven mostly by precipitation and evaporation of water (Broecker and Peng, 1982; Takahashi et al., 1993; Millero et al., 1998). $\mathrm{TCO}_{2}$, on the other hand, was linearly related to salinity only from the surface down to about $70 \mathrm{~m}$ (Fig. 7B), such that, in the mixed layer:

$$
\begin{gathered}
\mathrm{TCO}_{2}=65.5( \pm 3.7) \times S-304( \pm 124), \\
r^{2}=0.81, \quad n=75 .
\end{gathered}
$$

The divergent behaviors between TA and $\mathrm{TCO}_{2}$ indicate that additional processes could have played a significant role in the distribution of the latter.
In order to examine the contributions of the processes other than the changes in salinity to the variations in TA and $\mathrm{TCO}_{2}$, the effects of salinity were removed by normalizing them to a constant salinity of 33.5 by the method of Friis et al. (2003) in which the effect of the variability in the preformed concentrations at $S=0$ also may be minimized. Thus, the normalized TA and $\mathrm{TCO}_{2}$, or NTA and $\mathrm{NTCO}_{2}$, are given as

$\mathrm{NTA}=\mathrm{TA}+(33.5-S) \times 65.7$,

$\mathrm{NTCO}_{2}=\mathrm{TCO}_{2}+(33.5-S) \times 65.5$.

A salinity of 33.5 was chosen as the reference salinity since it was the average salinity in the mixed layer at the SEATS site during the sampling period. The other coefficients in the equations were the slopes of the relationships between TA and salinity (Eq. (2)) and $\mathrm{TCO}_{2}$ and salinity (Eq. (3)), respectively.

The variations in NTA and $\mathrm{NTCO}_{2}$ in the mixed layer were significantly smaller than those of TA and $\mathrm{TCO}_{2}$ (Fig. 6A and B). While TA and $\mathrm{TCO}_{2}$ in the mixed layer ranged between 2170 and $2230 \mu \mathrm{mol} \mathrm{kg}{ }^{-1}$, and 1860 and $1920 \mu \mathrm{mol} \mathrm{kg}^{-1}$, respectively, NTA and $\mathrm{NTCO}_{2}$ ranged only between 2190 and $2210 \mu \mathrm{mol} \mathrm{kg}^{-1}$, and 1880 and $1910 \mu \mathrm{mol} \mathrm{kg}{ }^{-1}$. Overall, the average seasonal fluctuations in NTA and $\mathrm{NTCO}_{2}, 8 \pm 4$ and $13 \pm 9 \mu \mathrm{mol} \mathrm{kg}^{-1}$ respectively, were less than half of those in TA and $\mathrm{TCO}_{2}, 40 \pm 10$ and $30 \pm 20 \mu \mathrm{mol} \mathrm{kg}^{-1}$. The intra-annual variations in NTA were not only small but also did not follow any consistent seasonal pattern (Fig. 6A). The average NTA in the mixed layer was $2200 \pm 5 \mu \mathrm{mol} \mathrm{kg}^{-1}$. Since the variations in NTA over the mean value were of a similar magnitude as the analytical uncertainty, the intra-annual variations in TA could be accounted for almost exclusively by the changes in salinity. If biogeochemical processes that could have altered TA, such as the formation of calcium carbonate, also occurred, their influence was small and was greatly obscured by the analytical uncertainty. A lower NTA could be noted in the summer of 2000 . However, without other corroborative data, further speculations on its significance would not be warranted.

In the case of $\mathrm{NTCO}_{2}$, the average value in the mixed layer was $1890 \pm 10 \mu \mathrm{mol} \mathrm{kg}^{-1}$. The variations over the mean were significantly larger than the analytical uncertainty. While the intra-annual fluctuations in $\mathrm{NTCO}_{2}$ in the mixed layer were less pronounced than those in $\mathrm{TCO}_{2}$, the seasonal pattern was largely maintained (Fig. 6B). $\mathrm{NTCO}_{2}$ rose to an annual maximum in the winter and fell to 
a minimum in the summer to fall. Since $\mathrm{NTCO}_{2}$ was higher in the subsurface Tropical Water (Fig. 7B), enhanced vertical mixing in the winter would have brought this water to the mixed layer and led to higher $\mathrm{NTCO}_{2}$ in the mixed layer. In addition, the lower temperature in the winter also could have enhanced the invasion of $\mathrm{CO}_{2}$ and led to an increase in $\mathrm{NTCO}_{2}$.

In the mixed layer, TA was also linearly related to $\mathrm{TCO}_{2}$ such that

$$
\begin{aligned}
\mathrm{TA} & =0.88( \pm 0.04) \times \mathrm{TCO}_{2}+540( \pm 81), \\
r^{2} & =0.85, \quad n=75 .
\end{aligned}
$$

While this linear relationship itself was hardly unexpected, since both TA and $\mathrm{TCO}_{2}$ were linearly related to salinity in the mixed layer, the slope, $0.88 \mu \mathrm{mol} \mathrm{mol}^{-1}$, indicates that aside from evaporation and precipitation, which would have yielded a slope of $+1 \mu \mathrm{mol} \mu \mathrm{mol}^{-1}$, other processes must also have been in play. Processes that could have lowered the slope include net photosynthesis, net invasion and net evasion of atmospheric $\mathrm{CO}_{2}$, which would result in slopes of $-0,+0$ and $-0 \mu \mathrm{mol} \mu \mathrm{mol}^{-1}$ respectively, and mixing with the Tropical Water whose ratio in the changes in TA to those in $\mathrm{TCO}_{2}$ was less than 1 .

Just as in TA and $\mathrm{TCO}_{2}, \mathrm{fCO}_{2}$ also increased with depth from around $370 \mu \mathrm{atm}$ at the sea surface to $500 \mu \mathrm{atm}$ below $150 \mathrm{~m}$ (Fig. 4E), and large seasonal variations were found in the top $50 \mathrm{~m}$ of the water column (Figs. 5C and 6C). In fact, among TA, $\mathrm{TCO}_{2}$ and $\mathrm{fCO}_{2}$, the seasonal variations in $\mathrm{fCO}_{2}$ followed the most regular and distinctly defined cycle. However, in contrast to TA and $\mathrm{TCO}_{2}$, its seasonal pattern followed that in temperature more closely than that in salinity. Thus, $\mathrm{fCO}_{2}$, at $340 \mu \mathrm{atm}$, was also at a minimum in the winter and it increased progressively through the spring and reached a maximum of $\sim 400 \mu \mathrm{atm}$ in the summer before it retreated steadily through the fall back to a minimum value in the winter (Fig. 6C).

In the mixed layer, $\mathrm{fCO}_{2}$ and potential temperature, $T$, were linearly related to each other (Fig. 8A) such that

$$
\begin{aligned}
& \mathrm{fCO}_{2}=8.1( \pm 1.0) \times T+141( \pm 29), \\
& r^{2}=0.79, \quad n=19 .
\end{aligned}
$$

The slope of this relationship, $8.1 \mu \mathrm{atm}{ }^{\circ} \mathrm{C}^{-1}$, was equivalent to $\sim 2.4 \%{ }^{\circ} \mathrm{C}^{-1}$. If the mixed layer were a close system, thermodynamic considerations would predict a temperature dependence of $4.2 \%{ }^{\circ} \mathrm{C}^{-1}$
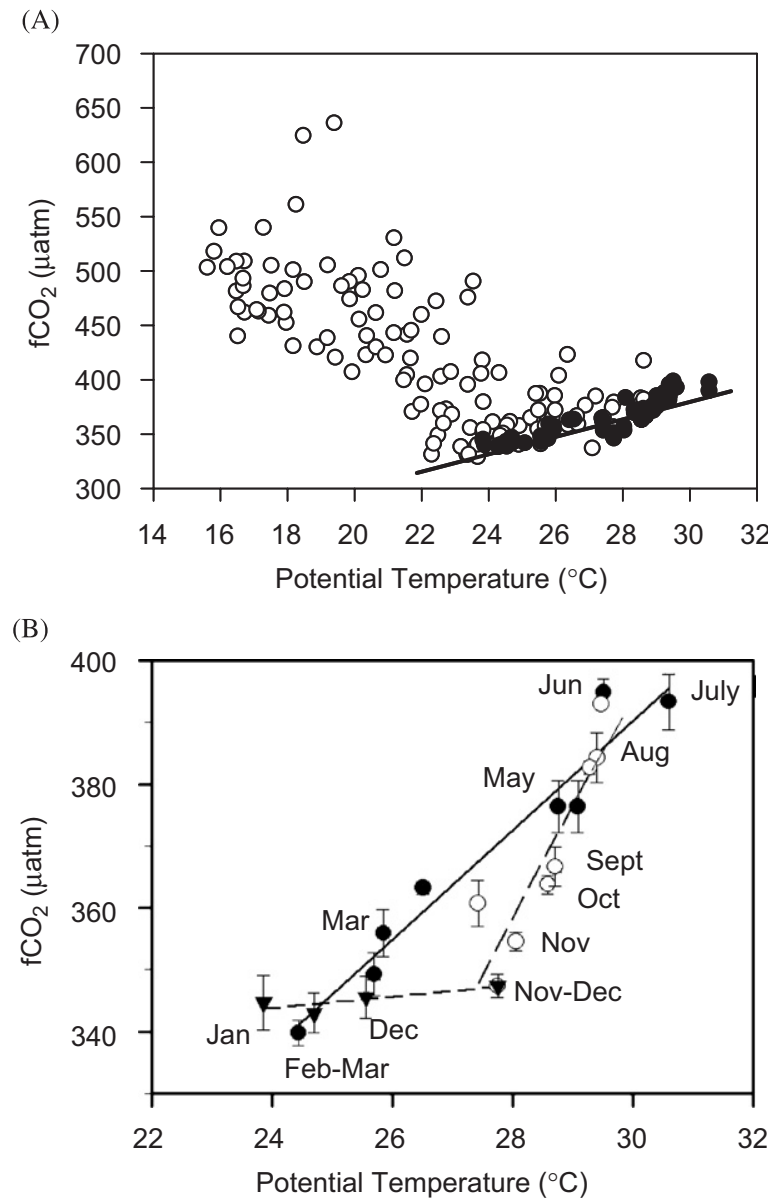

Fig. 8. The relationship between $\mathrm{fCO}_{2}$ and potential temperature (A) in the top $150 \mathrm{~m}(\bullet-$ in the mixed layer; $\bigcirc-$ bottom of mixed layer to $150 \mathrm{~m}$ ) and (B) in the mixed layer in different time periods in the year (•-late winter-summer (February-August); $\bigcirc$-late summer-early winter (August-December); $\mathbf{\nabla}$-winter (December-February) at the SEATS station between September 1999 and October 2003. The best fit line by a linear regression analysis of the data points from within the mixed layer only is shown in (A). The lines for February-August, August-December and December-February are shown in (B).

(Gordon and Jones, 1973; Takahashi et al., 1993). Obviously, the ocean is not exactly a close system. Nonetheless, the large discrepancy between the observed and predicted slope points to the possibility that processes other than temperature variations also might have played a role in the seasonal variations in $\mathrm{fCO}_{2}$.

The effect of temperature variations may be removed by normalizing $\mathrm{fCO}_{2}$ to a constant temperature using the following equation (Takahashi et al., 2002):

$\mathrm{NfCO}_{2}=\mathrm{fCO}_{2} \times \exp [27.6-T]$, 
where $\mathrm{NfCO}_{2}$ is the normalized $\mathrm{fCO}_{2}$ and $T$ is temperature in ${ }^{\circ} \mathrm{C}$. The average temperature in the mixed layer at the SEATS station, $27.6{ }^{\circ} \mathrm{C}$, was used as the reference temperature. Since the effect of temperature had already been removed, changes in $\mathrm{NfCO}_{2}$ would reflect primarily the influence of the invasion and evasion of atmospheric $\mathrm{CO}_{2}$, biological uptake or production of $\mathrm{CO}_{2}$ and mixing with other water masses. The intra-annual fluctuations in $\mathrm{NfCO}_{2}$ were comparable to those in $\mathrm{fCO}_{2}$, as it still varied by about $60 \mu \mathrm{atm}$, between 340 and $400 \mu \mathrm{atm}$ during the study period (Fig. 6C). However, the seasonal pattern became less well behaved and it was significantly different from that of $\mathrm{fCO}_{2}$, indicating that changes in temperature played a dominant but not exclusive role in the intra-annual variations in $\mathrm{fCO}_{2}$. In fact, the seasonal variations in $\mathrm{NfCO}_{2}$ were approximately out of phase with those in $\mathrm{fCO}_{2}$ so that the annual maximum in $\mathrm{NfCO}_{2}$ was found in the winter and the minimum was found in the summer. This seasonal pattern was more similar to that in $\mathrm{NTCO}_{2}$ (Fig. 6B) than that in $\mathrm{fCO}_{2}$ (Fig. 6C). The correspondence between $\mathrm{NfCO}_{2}$ and $\mathrm{NTCO}_{2}$ suggests that processes other than changes in salinity and temperature, such as biological activities and mixing with other water masses, might have affected $\mathrm{TCO}_{2}$ and $\mathrm{fCO}_{2}$ simultaneously.

The shallow subsurface waters between the bottom of the mixed layer and the core of the Tropical water were in the upper nutricline (Wong et al., 2002, 2007). Relative to the mixed layer, in these waters, $\mathrm{TCO}_{2}$ was higher, more variable at a given salinity, and it increased more abruptly with increasing salinity, which meant increasing depth, and the ratio in the changes in TA to those in $\mathrm{TCO}_{2}$ was lower (Figs. 4 and 7). Concomitantly, $\mathrm{fCO}_{2}$ was also elevated, more variable at a given temperature but increased, rather than decreased, with decreasing temperature (Fig. 8A), which also meant increasing depth. All these phenomena were consistent with the effect of the remineralization of organic matter at these depths.

\subsection{Processes controlling the carbonate system during different time periods in the year}

A more detailed analysis of the composite relationship between $\mathrm{fCO}_{2}$ and temperature in the mixed layer during the study period (Fig. 8B) indicates that it was actually made up of three approximately linear relationships representing three different time periods in the year: late winter-summer (February-August), late summer to early winter (August-December), and winter (December-February). The first time period covered most of the wet southwest monsoonal season, which stretches historically from June to September. The drier northeast monsoonal season is usually ushered in within the second time period, and it reaches a maximum during the third time period. The relationships of $\mathrm{fCO}_{2}$ to temperature during these time periods were:

Late winter to summer:

$$
\begin{gathered}
\mathrm{fCO}_{2}=8.9( \pm 0.9) \times T+125( \pm 24), \\
r^{2}=0.95, \quad n=8 .
\end{gathered}
$$

Late summer to early winter:

$$
\begin{gathered}
\mathrm{fCO}_{2}=18.3( \pm 3.6) \times T-155( \pm 104), \\
r^{2}=0.81, \quad n=8 .
\end{gathered}
$$

Winter:

$$
\begin{aligned}
\mathrm{fCO}_{2} & =0.9( \pm 0.4) \times T+322( \pm 11), \\
r^{2} & =0.67, \quad n=4 .
\end{aligned}
$$

The corresponding slopes expressed in percent were 2.4, 4.9 and $0.3 \%{ }^{\circ} \mathrm{C}^{-1}$. The deviations of these values from the thermodynamically controlled relationship, $4.2 \%{ }^{\circ} \mathrm{C}^{-1}$, were the largest during the winter and at a minimum during the late summer to early winter. These seasonally distinct relationships indicate that different processes may act as the dominant control of the inorganic carbonate system in the mixed layer in these three time periods. The contributing processes that have been identified in the previous discussions were: invasion of atmospheric $\mathrm{CO}_{2}$ to the mixed layer as a result of surface cooling and evasion of $\mathrm{CO}_{2}$ from the mixed layer to the atmosphere as a result of surface heating, net photosynthetic uptake, mixing with the subsurface Tropical Water, and evaporation and precipitation.

The observed changes in salinity, temperature and the carbonate system in the mixed layer during these three time periods and the major contributing processes together with their effects that could have accounted for the observed changes are shown in Fig. 9. In the late winter to summer from February to August (Fig. 9A), the progressive surface heat gain could have led to the evasion of $\mathrm{CO}_{2}$ and accounted for the simultaneous increase in temperature and $\mathrm{fCO}_{2}$ and decrease in $\mathrm{TCO}_{2}$ and $\mathrm{NTCO}_{2}$. The decrease in $\mathrm{NfCO}_{2}$ could be explained 
(A)

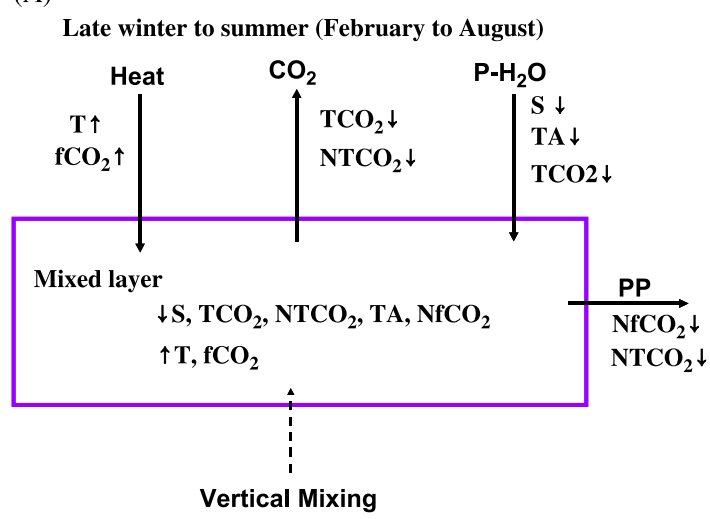

(B)

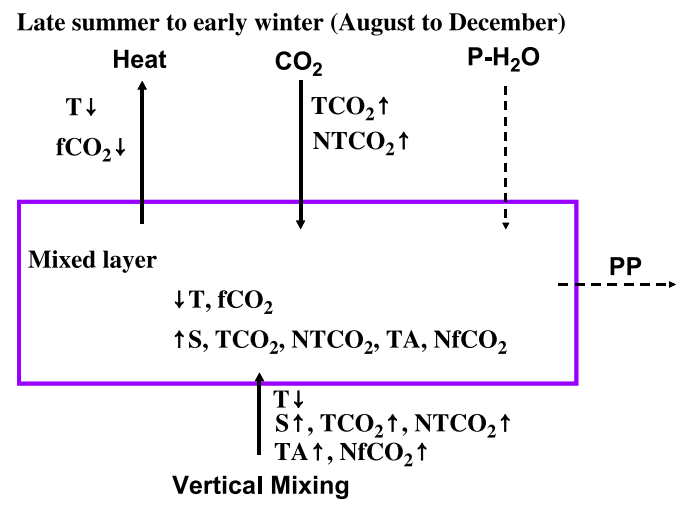

(C)

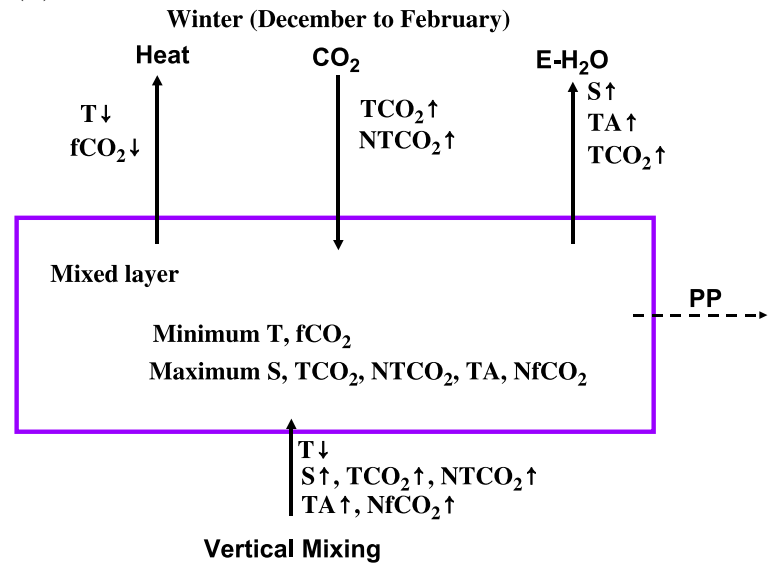

Fig. 9. Conceptual diagram of the contributing processes to the changes in salinity, temperature and the carbonate system in the mixed layer in (A) late winter to summer (February-August), (B) late summer to early winter (August-December), and (C) winter (December-February). Observed changes in the mixed layer are shown in the box. Effects due to various processes are shown next to the arrows. Thick solid line denotes major contributing process. Dashed line denotes minor process. $\mathrm{P}-\mathrm{H}_{2} \mathrm{O}$-input of water by net precipitation; $\mathrm{E}-\mathrm{H}_{2} \mathrm{O}$ - loss of water by net evaporation; $\uparrow$-increase; $\downarrow$-decrease. by a contemporaneous removal of inorganic carbon by net photosynthetic activities. The average primary production and the $\mathrm{f}$ ratio in the northern SCS have been estimated through modeling exercises to be $280-350 \mathrm{mg} \mathrm{C} \mathrm{m}^{-2} \mathrm{~d}^{-1}$ and 0.12 (Liu et al., 2002). This range of primary production agreed reasonably well with those measured directly at the SEATS station. The resulting new production would lead to a drawdown in $\mathrm{NTCO}_{2}$ of $12.5-15.5 \mu \mathrm{mol} \mathrm{kg}{ }^{-1}$, values that are similar to the observed decrease of $13 \mu \mathrm{mol} \mathrm{kg}{ }^{-1}$ during this time period. This suggests that carbon uptake in primary production could explain most, if not all, of the decrease in $\mathrm{NTCO}_{2}$. Nonetheless, the corresponding drawdown in nitrate plus nitrite in this period of time was only about $0.15 \mu \mathrm{M}$ (Tseng et al., 2005; Wong et al., 2007) and this could account for a drawdown of $\mathrm{NTCO}_{2}$ of only $\sim 2.5 \mu \mathrm{mol} \mathrm{kg}{ }^{-1}$ according to the Redfield stoichiometry. Thus, other sources of combined nitrogen would be needed for supporting the observed level of primary production. One possible candidate for this additional source of combined nitrogen is nitrogen fixation as its occurrence has been implicated by the distributions of the nutrients and community production at the SEATS station (Wong et al., 2002, 2007; Chou et al., 2006). The reduction in salinity and TA from the late winter to summer could have resulted from the excess precipitation over evaporation and the increasingly impeded vertical mixing with the more saline subsurface Tropical Water as the water column became increasingly better stratified during this warming period. The climatological average difference between precipitation and evaporation between 1971 and 2000 at Hong Kong, located at the western border of the northern SCS at a similar latitude, $22.5^{\circ} \mathrm{N}$, to that of the SEATS station, indicates that $77 \%$ of the annual precipitation occurs and precipitation is equal to 2.4 times that of evaporation during this period of time in the year (Hong Kong Observatory Climatological Information Services, 2007).

During the cooling period from the summer to the early winter (Fig. 9B), all the observed variations could be accounted for by the combination of the invasion of atmospheric $\mathrm{CO}_{2}$ and the increase vertical mixing with the Tropical Water as the temperature in the mixed layer decreased progressively and the vertical stratification was weakened. As a result, temperature and $\mathrm{fCO}_{2}$ decreased while, $\mathrm{S}, \mathrm{TCO}_{2}, \mathrm{NTCO}_{2}, \mathrm{TA}$, and $\mathrm{NfCO}_{2}$ increased. In this period of lower primary production and more 
limited vertical mixing, the relationship between $\mathrm{fCO}_{2}$ and temperature came closest to a close system that was controlled by thermodynamics alone (Eq. (10)). Since precipitation still exceeds evaporation during this time period in the year (Hong Kong Observatory Climatological Information Services, 2007), the latter could not have contributed to the increase in salinity, $\mathrm{TCO}_{2}$ and TA.

During the winter (Fig. 9C), the effects of surface heat loss and the accompanying invasion of atmospheric $\mathrm{CO}_{2}$ and vertical mixing reached a maximum. As a result, salinity, $\mathrm{TCO}_{2}, \mathrm{NTCO}_{2}$, TA and $\mathrm{NfCO}_{2}$ were at a maximum while temperature and $\mathrm{fCO}_{2}$ reached their minimum values. Evaporation exceeds precipitation during this time period in the year (Hong Kong Observatory Climatological Information Services, 2007). The excess evaporation also could have contributed to the higher salinity, TA and $\mathrm{TCO}_{2}$. While primary production was at a maximum in the winter at the SEATS station, its effect of lowering $\mathrm{NfCO}_{2}$ and $\mathrm{NTCO}_{2}$ was not obvious and had apparently been obscured by the effects of the other processes.

\subsection{Air-sea exchange of $\mathrm{CO}_{2}$ at the SEATS station}

The variations in $\mathrm{fCO}_{2 \mathrm{w}}, \mathrm{fCO}_{2 \mathrm{a}}, \Delta \mathrm{fCO}_{2}$, and the average monthly climatological wind speed over the study period are shown in Fig. 10. The $\mathrm{fCO}_{2 \mathrm{w}}$ exceeded $\mathrm{fCO}_{2 \mathrm{a}}$ most prominently in the summer and it dropped below $\mathrm{fCO}_{2 \mathrm{a}}$ during the winter. The $\Delta \mathrm{fCO}_{2}$ ranged from a maximum of about +30 to a minimum of $-20 \mu \mathrm{atm}$. The climatological wind speed ranged between 4 and $11 \mathrm{~m} \mathrm{~s}^{-1}$. Stronger wind was found in the winter during the northeast monsoon. The $\mathrm{CO}_{2}$ gas transfer velocity $(k)$ ranged between 2 and $12 \mathrm{~m} \mathrm{~d}^{-1}$ and its variations followed those in wind speed closely (Fig. 10C). The corresponding exchange fluxes of $\mathrm{CO}_{2}$ ranged between 2 and $-2 \mathrm{~mol} \mathrm{C} \mathrm{m}^{-2} \mathrm{yr}^{-1}$ (Fig. 10D). Similar fluxes were obtained by using the climatological or short term wind speeds (Table 1).

The invasion and evasion of $\mathrm{CO}_{2}$ occurred primarily in the winter and the summer respectively. While a net evasion also was found in the spring and the fall, the efluxes in these two seasons were minimal relative to that in the summer (Table 1). Relative to the three time periods in the year when different processes took turn to dominate in controlling the behaviors of the carbonate system in the mixed layer, the average influx in the winter was $1.2-1.4 \mathrm{~mol} \mathrm{C} \mathrm{m}^{-2} \mathrm{yr}^{-1}$. If this amount of $\mathrm{CO}_{2}$ was distributed uniformly in the mixed layer whose average thickness was about $70 \mathrm{~m}$, then it would have resulted in an increase in $\mathrm{NTCO}_{2}$ of about $5 \mu \mathrm{mol} \mathrm{kg}{ }^{-1}$. In comparison, the observed average increase in $\mathrm{NTCO}_{2}$ from the fall to the maximum concentration in the winter was $\sim 14 \mu \mathrm{mol} \mathrm{kg}{ }^{-1}$. From the late winter to the summer, the average eflux in this warming period was $\sim 0.4 \mathrm{~mol} \mathrm{C} \mathrm{m}^{-2} \mathrm{yr}^{-1}$. For a mixed-layer depth of $25 \mathrm{~m}$, this eflux would have resulted in a drawdown of $\mathrm{NTCO}_{2}$ of around $7 \mu \mathrm{mol} \mathrm{kg}{ }^{-1}$. The observed average decrease in $\mathrm{NTCO}_{2}$ from the winter to the late summer was $\sim 13 \mu \mathrm{mol} \mathrm{kg}{ }^{-1}$. In both cases, the estimated changes could constitute a significant faction of the observed changes. They affirm that the net air-sea exchange of $\mathrm{CO}_{2}$ was a significant but not the exclusive controlling mechanism of the changes in the carbonate species in the mixed layer. Between the late summer and early winter, the net air-sea exchange of $\mathrm{CO}_{2}$ was around 0 . Correspondingly, the relationship between $\mathrm{fCO}_{2}$ and temperature (Eq. (10)) in this period of time was most similar to that predicted from thermodynamic considerations alone among the three time periods.

For the year as a whole, there was a net invasion of atmospheric $\mathrm{CO}_{2}$ of $0.02 \pm 1$ and $0.01 \pm$ $0.9 \mathrm{~mol} \mathrm{C} \mathrm{m}^{-2} \mathrm{yr}^{-1}$ to the sea when climatological and short-term wind speeds were used in the estimations, respectively. Given the large uncertainties in these values, both values should be considered indistinguishable from zero. This suggests that the invasion and evasion of $\mathrm{CO}_{2}$ at the SEATS site basically balanced each other out over the year so that this part of the SCS was neither a significant source nor a significant sink of atmospheric $\mathrm{CO}_{2}$. While the $\Delta \mathrm{fCO}_{2}$ during and the length in the period of evasion were somewhat larger and longer than those in the period of invasion, the exchange coefficient was larger during the period of evasion as a result of the stronger northeast monsoon in the winter. These two opposing effects apparently cancelled each other out and led to a net exchange rate of about zero over the entire year.

Chou et al. (2005) estimated a net invasion of atmospheric $\mathrm{CO}_{2}$ of about $0.1 \mathrm{~mol} \mathrm{C} \mathrm{m}^{-2} \mathrm{yr}^{-1}$ at the SEATS site in 2002-2003. While the difference between this short-term value and the longer-term average reported here was small and well within the uncertainty in the modeling exercise, it points to the possibility of minor inter-annual variations. Zhai et al. (2005), based on underway $\mathrm{fCO}_{2}$ data collected primarily around the shelf and the slope areas along 

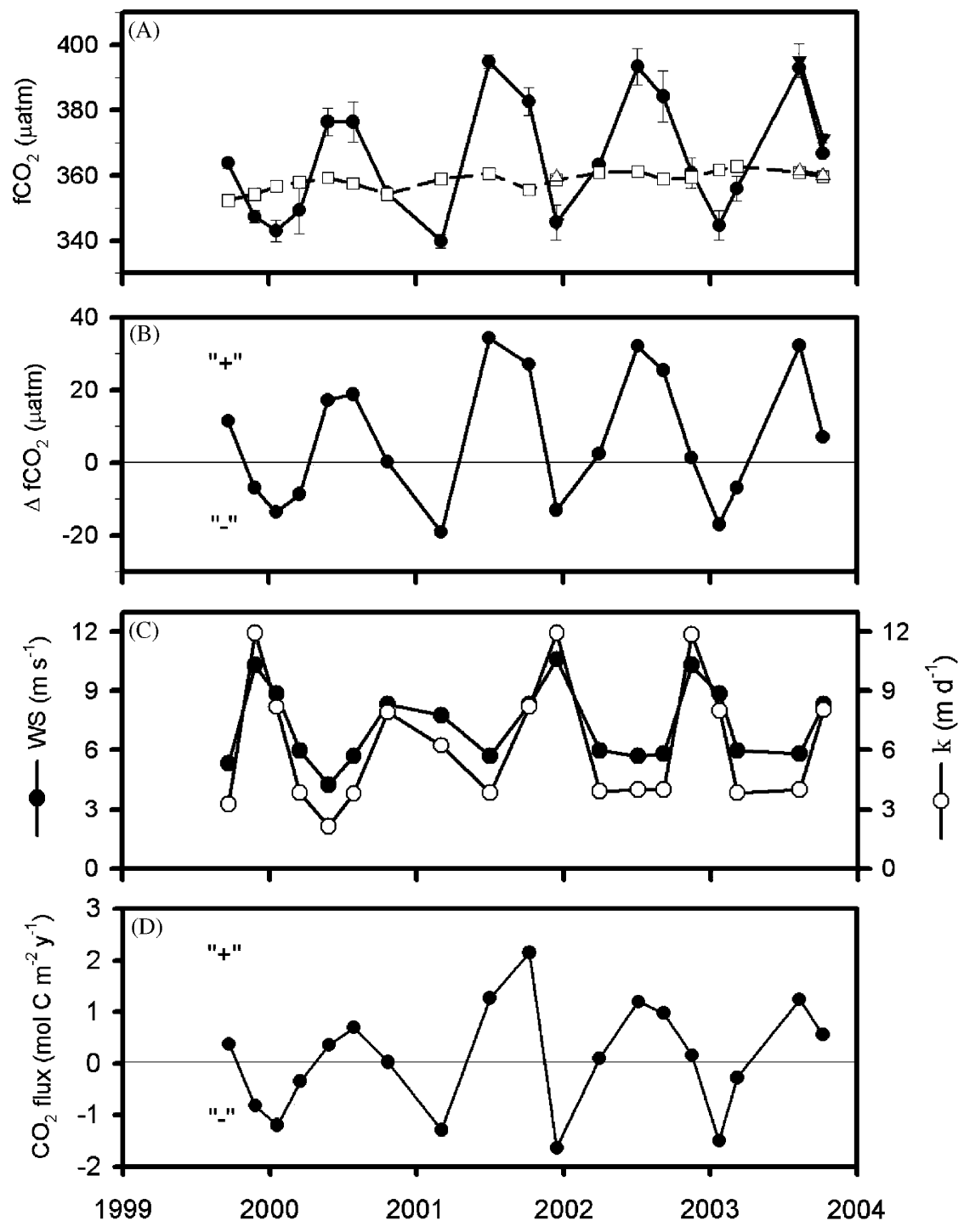

Fig. 10. Variations in (A) the average $\mathrm{fCO}_{2 \mathrm{w}}\left(\bullet\right.$ calculated; $\mathbf{\nabla}$ - underway) and $\mathrm{fCO}_{2 \mathrm{a}}(\square$ - estimated; $\triangle$ - underway) in the mixed layer, (B) the average $\Delta \mathrm{fCO}_{2}$ in the mixed layer, (C) the monthly average climatological wind speed $(\bullet)$ and gas transfer velocity $(k)(O)$, and $(\mathrm{D})$ $\mathrm{CO}_{2}$ flux in different sampling months in the year ("+": sea to air; "-": air to sea) at the SEATS station between September 1999 and October 2003.

southern China in the summer of 2000, the spring of 2001 and the fall of 2002, estimated a net evasion of $\mathrm{CO}_{2}$ of $0.3 \mathrm{~mol} \mathrm{C} \mathrm{m}^{-2} \mathrm{yr}^{-1}$ to the atmosphere. Their study suggests a slightly larger flux but, more interestingly, an opposite direction of exchange of $\mathrm{CO}_{2}$. Nonetheless, a direct comparison between their value and the value reported here may not be warranted. First, while fluxes estimated from underway $\mathrm{fCO}_{2}$ represent short term, almost instantaneous rates, fluxes estimated from the dissolved carbonate species represent longer term averages. Secondly, there were substantial spatial and tem- poral mismatches between the two studies. The study of Zhai et al. (2005) covered primarily shelf waters while this study focused on the oligotrophic open northern SCS. The sampling period in this study, 5 years, was substantially longer than that in the study of Zhai et al. (2005), in which winter was significantly under-sampled. Nonetheless, all the studies to date indicate that the northern SCS is not a significant source or sink of atmospheric $\mathrm{CO}_{2}$. This clearly distinguishes the SEATS site from the other two major open-ocean time series sites, as the influx estimated here was less than $10 \%$ of those 
Table 1

Average seasonal air-sea exchange flux of $\mathrm{CO}_{2}$ at the SEATS station

\begin{tabular}{lcc}
\hline Seasons & \multicolumn{2}{c}{ Exchange flux of $\mathrm{CO}_{2}\left(\mathrm{~mol} \mathrm{C} \mathrm{m}^{-2} \mathrm{yr}^{-1}\right)$} \\
\cline { 2 - 3 } & 1 & 2 \\
\hline Spring $(n=4)$ & $0.09 \pm 0.37$ & $0.04 \pm 0.34$ \\
Summer $(n=5)$ & $1.10 \pm 0.16$ & $1.02 \pm 0.02$ \\
Fall $(n=6)$ & $0.15 \pm 0.88$ & $0.10 \pm 0.66$ \\
Winter $(n=4)$ & $-1.43 \pm 0.43$ & $-1.21 \pm 0.43$ \\
Average & $-0.02 \pm 1.06$ & $-0.01 \pm 0.86$ \\
\hline
\end{tabular}

1-Estimated by using long-term climatological wind.

2-Estimated by using short-term wind.

Positive and negative values denote eflux and influx of $\mathrm{CO}_{2}$ to and from the atmosphere, respectively.

reported at the HOT and BATS sites where significant influxes of 0.7 (Winn et al., 1994) and 0.2-0.8 (Bates et al., 1996, 1998) $\mathrm{mol} \mathrm{Cm}^{-2} \mathrm{yr}^{-1}$ were reported. The difference may be accounted for by the weaker solubility and biological pump at the SEATS site as a result of its consistently higher surface temperatures and stronger stratification year round (Table 2).

Marginal seas have been hypothesized as a significant global net sink of atmospheric $\mathrm{CO}_{2}$ ( $\sim 0.1 \mathrm{GtC} \mathrm{yr}^{-1}$ by Liu et al., 2000; $\sim 0.4 \mathrm{GtC} \mathrm{yr}^{-1}$ by Thomas et al., 2004). However, the sites that have been studied to date, the East China Sea (Chen and Wang, 1999; Peng et al., 1999; Tsunogai et al., 1999; Wang et al., 2000), the Baltic Sea (Thomas, and Schneider, 1999), the North Sea (Thomas et al., 2004), the European shelf (Frankignoulle and Borges, 2001), the Mid-Atlantic Bight (DeGrandpre et al., 2002) and the shelf off New Jersey (Boehme et al., 1998), were situated primarily in the midlatitudes. While the reported net annual influxes at these sites ranged from 0.6 to $3 \mathrm{~mol} \mathrm{C} \mathrm{m}^{-2} \mathrm{yr}^{-1}$, the influx in the northern SCS was at best only a few percent of these fluxes. Thus, in terms of their role as a source or sink of atmospheric $\mathrm{CO}_{2}$, marginal seas located at low latitudes, such as the northern SCS, may not function in a similar fashion as those located at higher latitudes. The quantitative importance of the margin seas as a sink of atmospheric $\mathrm{CO}_{2}$ may be smaller than previously thought (Cai and Dai, 2004).

\subsection{Interannual variability of the $\mathrm{NTCO}_{2}$ and $\mathrm{fCO}_{2}$ at the SEATS station}

While temporal variations in $\mathrm{NTCO}_{2}$ and $\mathrm{fCO}_{2}$ at the SEATS station were dominated by intra-annual variations, there were also suggestions of subtle long-term inter-annual variations (Fig. 6B and C). The average $\mathrm{NTCO}_{2}$ and $\mathrm{fCO}_{2}$ in the mixed layer were related to time, $t$ in years, as follows:

$$
\begin{aligned}
\mathrm{NTCO}_{2} & =1.5( \pm 1.4) \times t+1887.2( \pm 4.4), \\
r^{2} & =0.05, \quad n=19, \\
\mathrm{fCO}_{2} & =4.2( \pm 3.2) \times t+353.9( \pm 9.6), \\
r^{2} & =0.09, \quad n=19 .
\end{aligned}
$$

The uncertainties in these estimates were inherently large as a result of the large amplitudes in the short term intra-annual variations. The $\mathrm{fCO}_{2}$ increased at a rate of $4.2 \pm 3.2 \mu \mathrm{atm} \mathrm{yr}^{-1}$, or $\sim 1.1 \% \mathrm{yr}^{-1}$. The rate of increase in atmospheric $\mathrm{CO}_{2}$ observed at the Mauna Loa Observatory was $1.6 \mu \mathrm{atm} \mathrm{yr}^{-1}$ (or $\sim 0.45 \% \mathrm{yr}^{-1}$ ) during the sampling period (Keeling and Whorf, 2004) and the atmospheric $\mathrm{fCO}_{2}$ that was measured occasionally at the SEATS station by the underway system agreed well (average deviation $\leqslant 1 \mu \mathrm{atm}$ ) with those found contemporaneously at that Observatory. If the results observed at Mauna Loa was also representative of the conditions at the SEATS station, then, the $\mathrm{fCO}_{2}$ in the mixed layer at the SEATS station was increasing at a faster rate than that in its overlying air so that the two were not at equilibrium with each other. Furthermore, if this trend were real and it continues, the northern SCS, if not now, will eventually become a net source of $\mathrm{CO}_{2}$ to the atmosphere.

The trend of increasing $\mathrm{NTCO}_{2}$ with time, at a rate of $1.5 \pm 1.4 \mu \mathrm{mol} \mathrm{kg}^{-1} \mathrm{yr}^{-1}$ (or $\sim 0.1 \% \mathrm{yr}^{-1}$ ), is consistent with the continued invasion of $\mathrm{CO}_{2}$ to the surface oceans as a result of the steadily increasing atmospheric $\mathrm{fCO}_{2}$. The Revelle factor under the local conditions at the SEATS station was estimated to be about 9. By using this Revelle factor, the increase in $\mathrm{NTCO}_{2}$ as a result of the reported rate of increase in atmospheric $\mathrm{CO}_{2}\left(1.6 \mu \mathrm{atm} \mathrm{yr}^{-1}\right)$ could be estimated to be $0.9 \mu \mathrm{mol} \mathrm{kg} \mathrm{yr}^{-1}$ (Winn et al., 1998). Alternatively, since the estimated invasion rate of atmospheric $\mathrm{CO}_{2}$ was $0.02 \mathrm{~mol} \mathrm{C} \mathrm{m}^{-2} \mathrm{yr}^{-1}$ at the SEATS station, if this amount of $\mathrm{CO}_{2}$ was mixed uniformly into the mixed layer with an annual average thickness of $40 \mathrm{~m}$, the resulting increase in $\mathrm{NTCO}_{2}$ in the mixed layer would be $0.5 \mathrm{~mol} \mathrm{C} \mathrm{m}^{-2} \mathrm{yr}^{-1}$. In both cases, the observed rates of increase in $\mathrm{NTCO}_{2}$ were substantially larger than the estimated value.

These higher long-term rates of increase of $\mathrm{fCO}_{2}$ and $\mathrm{NTCO}_{2}$ in the mixed layer relative to what may 
Table 2

Characteristics in the hydrographic properties and the carbonate species at the SEATS, HOT and BATS stations

\begin{tabular}{|c|c|c|c|}
\hline $\mathrm{CO}_{2}$ variables & SEATS $^{\mathrm{a}}$ & $\mathrm{HOT}^{\mathrm{b}}$ & BATS $^{\mathrm{c}}$ \\
\hline \multicolumn{4}{|l|}{ Sal. } \\
\hline Range & $33.1-33.9$ & $34.6-35.3$ & $36.2-36.9$ \\
\hline$\Delta$ & $0.6 \pm 0.2(0.3-0.9)$ & 0.7 & 0.7 \\
\hline $\operatorname{Max}$ & Winter & nct & Winter \\
\hline Min & Spring and fall & nct & Summer-early fall \\
\hline \multicolumn{4}{|l|}{ Temp. } \\
\hline Range & $24-30$ & $22-27$ & $19-29$ \\
\hline$\Delta$ & $5 \pm 1(4-6)$ & 5 & $8-10$ \\
\hline Max & Summer & Fall & Late summer \\
\hline Min & Winter & Late winter-spring & Winter \\
\hline \multicolumn{4}{|l|}{$T A$} \\
\hline Range & $2170-2230$ & $2297-2317$ & $2365-2405$ \\
\hline$\Delta$ & $40 \pm 10(30-60)$ & 20 & 40 \\
\hline $\operatorname{Max}$ & Winter & net & Winter \\
\hline Min & Spring and fall & nct & Summer-early fall \\
\hline \multicolumn{4}{|l|}{$N T A$} \\
\hline Range & $2190-2210$ & $2295-2315$ & $2385-2396$ \\
\hline$\Delta$ & $8 \pm 4(5-15)$ & 20 & $10-12$ \\
\hline Max & nct & nct & nct \\
\hline Min & nct & nct & nct \\
\hline \multicolumn{4}{|l|}{$\mathrm{TCO}_{2}$} \\
\hline Range & $1860-1920$ & $1945-1980$ & $2015-2065$ \\
\hline$\Delta$ & $30 \pm 20(10-60)$ & 35 & $30-40$ \\
\hline $\operatorname{Max}$ & Winter & nct & Late winter-spring \\
\hline Min & Spring and fall & nct & Late summer-fall \\
\hline \multicolumn{4}{|l|}{$\mathrm{NTCO}_{2}$} \\
\hline Range & $1880-1910$ & $1960-1975$ & $2010-2050$ \\
\hline$\Delta$ & $13 \pm 9(5-30)$ & 15 & 40 \\
\hline Max & Late winter & Late winter-spring & Late winter-spring \\
\hline Min & Summer/fall & Fall & Late summer-fall \\
\hline \multicolumn{4}{|l|}{$\mathrm{fCO}_{2}$} \\
\hline Range & $340-395$ & $320-360$ & $310-410$ \\
\hline$\Delta$ & $40 \pm 10(30-60)$ & 40 & $80-100$ \\
\hline $\operatorname{Max}$ & Summer & Fall & Late summer \\
\hline Min & Winter & Late winter-Spring & Winter \\
\hline \multicolumn{4}{|l|}{$\mathrm{NfCO}_{2}$} \\
\hline Range & $346-404$ & - & $310-390$ \\
\hline$\Delta$ & $40 \pm 10(30-60)$ & - & 80 \\
\hline $\operatorname{Max}$ & Winter & - & Late winter-spring \\
\hline Min & Summer/fall & - & Late summer-fall \\
\hline Duration & 1999-2003 & 1988-1995 & 1988-1998 \\
\hline $\begin{array}{l}\Delta \mathrm{NTCO}_{2} / \Delta T \\
\left(\mu \mathrm{mol} \mathrm{kg}-1 \mathrm{yr}^{-1}\right)\end{array}$ & $\begin{array}{l}1.5 \pm 1.4 \\
\left(\sim 0.1 \% \mathrm{yr}^{-1}\right)\end{array}$ & 1 & $\begin{array}{l}1.6 \pm 5.8 \\
\left(0.1 \% \mathrm{yr}^{-1}\right)\end{array}$ \\
\hline $\begin{array}{l}\Delta \mathrm{fCO}_{2 \mathrm{w}} / \Delta T \\
\left(\mu \mathrm{atm} \mathrm{yr} \mathrm{r}^{-1}\right)\end{array}$ & $\begin{array}{l}4.2 \pm 3.2 \\
\left(1.1 \% \mathrm{yr}^{-1}\right)\end{array}$ & - & $\begin{array}{l}1.4 \pm 10.7 \\
\left(0.38 \% \mathrm{yr}^{-1}\right)\end{array}$ \\
\hline$\Delta \mathrm{fCO}_{2 \mathrm{a}} / \Delta T$ & 1.6 & 1.2 & 1.3 \\
\hline$\left(\mu \mathrm{atm} \mathrm{yr}{ }^{-1}\right)$ & $\left(0.45 \% \mathrm{yr}^{-1}\right)$ & $\left(0.34 \% \mathrm{yr}^{-1}\right)$ & $\left(0.37 \% \mathrm{yr}^{-1}\right)$ \\
\hline
\end{tabular}

$\Delta$ Amplitude of intra-annual fluctuation.

nct: No clear seasonal trend.

${ }^{\mathrm{a}}$ This work.

${ }^{\mathrm{b}}$ Winn et al. (1994, 1998).

${ }^{\mathrm{c}}$ Bates et al. (1996, 1998), Bates (2001). 
be supported by the increasing atmospheric invasion of $\mathrm{CO}_{2}$ suggest that processes, such as a longterm changes in hydrographic conditions, could have contributed to these variations. Nonetheless, it should be pointed out that the estimations of these rates involved large uncertainties. While the present data set has indicated some interesting trends and has pointed out an intriguing outstanding issue, they need to be confirmed by a longer-term data record.

\subsection{Comparison to HOT and BATS station}

The characteristics of the seasonal variations in salinity, temperature and the carbonate species in the mixed layer at the SEATS, HOT (Winn et al., 1994, 1998) and BATS (Bates et al., 1996, 1998; Bates, 2001) stations are listed in Table 2. The upper layer at the SEATS station was fresher and warmer than that at the other two stations as a result of its closer proximity to major fresh water inputs and lower latitude and these could have contributed to the correspondingly lower $\mathrm{TA}, \mathrm{TCO}_{2}$ and higher $\mathrm{fCO}_{2}$.

In general, tropical waters tend to be permanently stratified while temperate waters undergo seasonal destratification in the winter and stratification in the summer. However, at the SEATS station, the unique combined action of surface cooling and the strong northeast monsoon in the winter on a shallow nutricline leads to an enhanced vertical mixing (Tseng et al., 2005). As a result, while the SEATS station is located at a latitude closer to that of the HOT station than that of the BATS station and its upper layer communicates freely with the north Pacific, its hydrographic behavior is more similar to those at the BATS station in the temperate north Atlantic than to those at the HOT station in the subtropical north Pacific. For example, while no clear seasonal trends in TA, $\mathrm{TCO}_{2}$ and $\mathrm{NTCO}_{2}$ could be observed at the HOT station, a distinct maximum in the winter was found at both the SEATS and the BATS station. The resulting intra-annual fluctuations in TA and $\mathrm{TCO}_{2}$ at the SEATS stations were larger than those at the HOT station but similar to those at the BATS station.

Even thought there were consistent patterns in the intra-annual variations in TA at the SEATS and BATS stations, such patterns were removed once the values were normalized to a specified salinity, confirming that the variations in TA in the open oceans are controlled mostly by those physical processes that can lead to changes in salinity: evaporation, precipitation and mixing among water masses. On the other hand, regular patterns in the intra-annual variations in $\mathrm{NTCO}_{2}$ were discernible at all three sites. Furthermore, while the amplitude in the intra-annual fluctuations in $\mathrm{NTCO}_{2}$ was not much smaller than that in $\mathrm{TCO}_{2}$ at the BATS station, it was only a half or less of that in $\mathrm{TCO}_{2}$ at the SEATS and HOT sites. These indicate that the variations in $\mathrm{TCO}_{2}$ were not caused by changes in salinity alone. Moreover, the contribution from the other processes, such as biological uptake, was more significant at the BATS station than at the SEATS and HOT stations which were biologically less productive.

Distinct patterns were found in the intra-annual variations in $\mathrm{fCO}_{2}$ and $\mathrm{NfCO}_{2}$ at both the BATS and SEATS stations. In the former case, the patterns followed those in temperature closely. These indicate that changes in temperature were a generally significant, but not the exclusive, driving mechanism in the variations in $\mathrm{fCO}_{2}$. While the patterns in the intra-annual variations in $\mathrm{fCO}_{2}$ and $\mathrm{NfCO}_{2}$ were similar at the BATS station, they were distinctly different at the SEATS station. At the latter station, the pattern in the intra-annual variations in $\mathrm{NfCO}_{2}$ actually followed that in $\mathrm{NTCO}_{2}$, rather than that in temperature, closely. These suggest that the contributions from processes other than changes in temperature to the variations in $\mathrm{fCO}_{2}$ could be variable and site-specific.

Inter-annually, $\mathrm{NTCO}_{2}$ increased with time at all three stations at rates of $1-2 \mu \mathrm{mol} \mathrm{kg} \mathrm{kr}^{-1}$. The $\mathrm{fCO}_{2}$ in the mixed layer was also increasing with time at the SEATS and BATS station at rates of 4 and $1 \mu \mathrm{mol} \mathrm{kg} \mathrm{yr}^{-1}$. Within the inherently large uncertainties in these estimations, their qualitative coherence suggests that these trends may be a global phenomenon and they are consistent with the expected response of the ocean to an increasing influx of atmospheric $\mathrm{CO}_{2}$ to the ocean as atmospheric $\mathrm{fCO}_{2}$ increases with time.

\section{Conclusions}

In contrast to what is expected in low-latitude waters, TA, $\mathrm{TCO}_{2}$ and $\mathrm{fCO}_{2}$ in the mixed layer at the SEATS station followed distinct patterns in their intra-annual variations. TA and $\mathrm{TCO}_{2}$ were conspicuously higher in the winter. The enhanced vertical mixing in the winter as a result of the joint 
forcing of surface cooling and the strong northeast monsoon, a process unique to the SEATS station among the global time-series stations, brought the subsurface Tropical Water, which is elevated in salinity, TA and $\mathrm{TCO}_{2}$, to the mixed layer and played a central role in giving rise to these intraannual variations. The intra-annual variations in $\mathrm{fCO}_{2}$, on the other hand, followed the changes in temperature more closely than those in salinity. It was at a minimum in the winter and it rose to a maximum in the summer.

While the intra-annual variations in TA in the mixed layer could be accounted for almost completely by the changes in salinity so that no consistent pattern could be found in the variations in NTA, distinct patterns were still conspicuous in the intra-annual variations in $\mathrm{NTCO}_{2}$ and in $\mathrm{NfCO}_{2}$. Between the late winter and the summer, uptake of carbon in primary production and the evasion of $\mathrm{CO}_{2}$ from the sea to the atmosphere were the major processes that could have resulted in the drawdown of $\mathrm{NTCO}_{2}$ and $\mathrm{NfCO}_{2}$. Between late summer and the winter, changes in the carbonate species were controlled mostly by the invasion of atmospheric $\mathrm{CO}_{2}$ as a result of surface cooling and the increased mixing with the subsurface Tropical Water and the effect of these two processes reached a maximum in the winter.

The northern South China Sea was neither a significant source nor sink of atmospheric $\mathrm{CO}_{2}$. While the slightly longer period of net evasion of $\mathrm{CO}_{2}$ to the atmosphere in the spring to the fall and the larger difference in $\mathrm{fCO}_{2}$ between the atmosphere and the mixed layer during this period of evasion would boost the eflux, their effects were approximately cancelled out by the higher gas transfer velocity as a result of the higher wind speed during the period of invasion in the winter. The resulting annual net invasion flux of $\sim 0.02 \mathrm{~mol} \mathrm{C} \mathrm{m}^{-2} \mathrm{yr}^{-1}$ was indistinguishable from zero. The hypothesis that marginal seas may be a significant sink of atmospheric $\mathrm{CO}_{2}$ needs to be reexamined since it was based on results from marginal seas that are situated primarily in the temperate zone. Marginal seas in the low latitudes, such as the SCS may be much less effective a sinks for atmospheric $\mathrm{CO}_{2}$.

Inter-annually, $\mathrm{NTCO}_{2}$ increased with time at rates of similar magnitude at the SEATS, HOT and BATS stations, suggesting that this may be a global phenomenon. The increase in $\mathrm{NTCO}_{2}$ with time is consistent with an increase in the invasion of $\mathrm{CO}_{2}$ from the atmosphere to the global ocean as a result of the progressive increase in atmospheric $\mathrm{CO}_{2}$.

\section{Acknowledgements}

We are grateful to the captains, crew and technicians of R/V Ocean Research I and III for their assistance in sampling, to C.T.A. Chen and S.L. Wang for technical support in carbonate measurements, to T.-D. Sue, P.-W. Chiang, Y.J. Wang and L.-F. Huang in sample collection and sample analyses for ancillary data, and to C.-C. Tsung in data processing and to Y.-H. Li, F.K. Shiah, C.-C. Chen, S.C. Kao, L.S. Wen, C.S. Liu, and the staff of the National Center for Ocean Research (NCOR) for logistic supports and assistance in field work. A thorough review of an earlier draft by A. Dickson has led to significant improvements in this manuscript. This work was supported by the National Science Council of Taiwan, Republic of China under Grant numbers NSC 882119-M-002-002, 89-2119-M-002-016, 90-2119-M002-016, 91-2119-M-002-031, 92-2119-M-002-015 NSC, NSC 93-2611-M-002-017, 94-2119-M-002027 and NSC 94-2611-M-002-019 to the National Center for Ocean Research (NCOR), National Taiwan University for the SEATS (SouthEast Asian Time-series Study) program. This is NCOR contribution no. 108 .

\section{References}

Bates, N.R., 2001. Interannual variability of oceanic $\mathrm{CO}_{2}$ and biogeochemical properties in the Western North Atlantic subtropical gyre. Deep-Sea Research II 48, 1507-1528.

Bates, N.R., Michaels, A.F., Knap, A.H., 1996. Seasonal and interannual variability of oceanic carbon dioxide species at the US JGOFS Bermuda Atlantic-series Study (BATS) site. Deep-Sea Research II 43, 347-383.

Bates, N.R., Takahashi, T., Chipman, D.W., Knap, A.H., 1998. Variability of $\mathrm{pCO}_{2}$ on diel to seasonal timescales in the Sargasso Sea. Journal of Geophysical Research 103, 15567-15585.

Boehme, S.E., Sabine, C.L., Reimer, C.E., 1998. $\mathrm{CO}_{2}$ fluxes from a coastal transect: a time-series approach. Marine Chemistry 63, 49-67.

Bradshaw, A.L., Brewer, P.G., Shafer, D.K., William, R.T., 1981. Measurement of total carbon dioxide and alkalinity by potentiometric titration in the GEOSECS program. Earth and Planetary Science Letters 55, 99-115.

Broecker, W.S., Peng, T.-H., 1982. Tracers in the Sea. Eldigio Press, Lamont-Doherty Geological Observatory of Columbia University, Palisades, New York, 690pp.

Butler, J.N., 1992. Alkalinity titration in seawater: how accurately can the data be fitted by an equilibrium model. Marine Chemistry 38, 251-282. 
Cai, W.J., Dai, M.H., 2004. Comment on "Enhanced open ocean storage of $\mathrm{CO}_{2}$ from shelf sea pumping". Science 306, 1477c.

Capone, D.G., Zehr, J.P., Paerl, H.W., Bergman, B., Carpenter, F.J., 1997. Trichodesmium, a globally significant marine cyanobacterium. Science 276, 122-1229.

Chao, S.Y., Shaw, P.T., Wu, S.Y., 1996a. Deep water ventilation in the South China Sea. Deep-Sea Research I 43, 445-466.

Chao, S.Y., Shaw, P.T., Wu, S.Y., 1996b. El Niño modulation of the South China Sea circulation. Progress in Oceanography 38, 51-93.

Chen, C.T.A., Wang, S.L., 1999. Carbon, alkalinity and nutrient budgets on the East China Sea continental shelf. Journal of Geophysical Research 104 (C9), 20675-20686.

Chou, W.C., Sheu, D.D., Chen, C.T.A., Wang, S.L., Tseng, C.M., 2005. Seasonal variability of carbon chemistry at the SEATS time-series site, northern South China Sea between 2002 and 2003. Terrestrial Atmospheric and Oceanic Sciences 16, 445-465.

Chou, W.C., Lee, Y.L., Shih, Y.Y., Sheu, D.D., Han, C.A., Cho, C.L., Tseng, C.M., Yang, Y.J., 2006. Estimated net community production during the summer time at the SEATS timeseries study site, northern South China Sea: implications for nitrogen fixation. Geophysical Research Letters 33, L22610.

Chou, W.C., Sheu, D.D., Lee, B.S., Tseng, C.M., Chen, C.T.A., Wang, S.L., Wong, G.T.F., 2007. Depth distributions of alkalinity, $\mathrm{TCO}_{2}$ and $\mathrm{d}^{13} \mathrm{C}_{\mathrm{TCO}}$ at the SEATS time-series site, in the northern South China Sea. Deep-Sea Research II, this issue [doi:10.1016/j.dsr2.2007.05.002].

DeGrandpre, M.D., Olbu, G.J., Beatty, C.M., Hammar, T.R., 2002. Air-sea $\mathrm{CO}_{2}$ fluxes on the US Middle Atlantic Bight. Deep-Sea Research II 49, 4355-4367.

Dickson, A.G., 1981. An exact definition of total alkalinity and a procedure for the estimation of alkalinity and total inorganic carbon from titration data. Deep-Sea Research I 28, 609-623.

Dickson, A.G., 1992. The development of alkalinity concept in marine chemistry. Marine Chemistry 40, 49-63.

Dickson, A.G., Millero, F.J., 1987. A comparison of the equilibrium constants for the dissociation of carbonic acid in seawater media. Deep-Sea Research I 34, 1733-1743.

DOE, 1994. Handbook of methods for the analysis of the various parameters of the carbon dioxide system in seawater. In: Dickson A.G., Goyet, C. (Eds.), US Department of Energy $\mathrm{CO}_{2}$ science Team Report, version 2, unpublished manuscript.

Feely, R.A., Sabine, C.L., Lee, K., Berelson, W., Kleypas, J., Fabry, V.J., Millero, F.J., 2004. Impact of anthropogenic $\mathrm{CO}_{2}$ on the $\mathrm{CaCO}_{3}$ system in the oceans. Science 305, 362-366.

Frankignoulle, M., Borges, A.V., 2001. European continental shelf as a significant sink for atmospheric carbon dioxide. Global Biogeochemical Cycles 15, 569-576.

Friis, K., Körtzinger, A., Wallace, D.W.R., 2003. The salinity normalization of marine inorganic carbon chemistry data. Geophysical Research Letters 30, 1085.

Gordon, L.I., Jones, L.B., 1973. The effect of temperature on carbon dioxide partial pressure in seawater. Marine Chemistry $1,317-322$.

Hong Kong Observatory Climatological Information Services, 2007. 〈www.hko.gov.hk/cis/normal/1971_2000/normals_e.htm〉.

Houghton, J.T., Ding, Y., Griggs, D.J., Noguer, M., van der Linden, P.J., Xiaosu, D., 2001. Climate Change 2001: the Scientific Basis contribution of working group I to the third assessment report of the Intergovernmental Panel on Climate Change. Cambridge University Press, Cambridge, 944pp.

IPCC, 2001. The Third assessment report of the Intergovernmental Panel on Climate Change (IPCC). Cambridge University Press, Cambridge, UK, and New York, USA.

Johnson, K.M., Wills, K.D., Butler, D.B., Johnson, W.K., Wong, C.S., 1993. Coulometric total carbon dioxide analysis for marine studies: maximizing the performance of an automated gas extraction system and coulometric detector. Marine Chemistry 44, 167-188.

Karl, D.M., Bates, N., Emerson, S., Harrison, P.J., Jeandal, C., Liu, K.K., Marty, J.C., Michaels, A.F., Miquel, J.C., Neuer, S., Nojiri, Y., Wong, C.S., 2003. Temporal studies of biogeochemical processes in the world's oceans during the JGOFS era. In: Fasham, M.J.R. (Ed.), Ocean Biogeochemistry: the Role of the Ocean Carbon Cycle in Global Change, IGBP Book Series. Springer, Berlin, pp. 239-267.

Keeling, C.D., Whorf, T.P., 2004. Atmospheric $\mathrm{CO}_{2}$ records from sites in the SIO air sampling network. In: Trends: a Compendium of Data on Global Change. Carbon Dioxide Information Analysis Center, Oak Ridge National Laboratory, US Department of Energy, Oak Ridge, TN.

Lewis, E., Wallace, D.W.R., 1998. Program developed for $\mathrm{CO}_{2}$ system calculations, Carbon Dioxide Information Analysis Center, Report ORNL/CDIAC-105, Oak Ridge Nat. Laboratory, Tenn., USA.

Lin, I.I., Liu, W.T., Wu, C.C., Wong, G.T.F., Hu, C., Chen, Z., Liang, W.D., Liu, K.K., 2003. New evidence for enhanced ocean primary production triggered by tropical cyclone. Geophysical Research Letters 30, 1781.

Lin, I.-I., Chen, J.-P., Wong, G.T.F., Huang, C.-W., Lien, C.-C., 2007. Aerosol input to the South China Sea: results from the moderate resolution imaging spectroradiometer, the quick scatterometer, and the measurements of pollution in the Troposphere Sensor. Deep-Sea Research II, this issue [doi:10.1016/j.dsr2.2007.05.013].

Liss, P.S., Slater, P.G., 1974. Flux gases across the air-sea interface. Nature 247, 181-184.

Liu, K.K., Atkinson, L., Chen, C.T.A., Gao, S., Hall, J., Macdonald, R.W., McManus, L.T., Quiñones, R., 2000. Exploring continental margin carbon fluxes on a global scale. EOS, Transactions, American Geophysical Union 81, 641-644.

Liu, K.K., Chao, S.Y., Shaw, P.T., Gong, G.C., Chen, C.C., Tang, T.Y., 2002. Monsoon-forced chlorophyll distribution and primary production in the South China Sea: observations and a numerical study. Deep-Sea Research I 49, 1387-1412.

Mehrbach, C., Culberson, C.H., Hawley, J.E., Pytkowicz, R.M., 1973. Measurement of the apparent dissociation constants of carbonic acid in seawater at atmospheric pressure. Limnology and Oceanography 18, 897-907.

Millero, F.J., Zhang, J.Z., Lee, K., Campelle, D., 1993. Titration alkalinity of seawater. Marine Chemistry 44, 269-280.

Millero, F.J., Lee, K., Roche, M., 1998. Distribution of alkalinity in the surface waters of the major oceans. Marine Chemistry $60,111-130$.

Peng, T.H., Hung, J.J., Wanninkhof, R., Millero, F.J., 1999. Carbon budget in the East China Sea in spring. Tellus 51B, 531-540.

Royal Society, 2005. Ocean acidification due to increasing atmospheric carbon dioxide. Document number 12/05, Royal Society, London, UK. 
SCOR, 1985. Oceanic $\mathrm{CO}_{2}$ measurements. Res. 3rd Meet. Working Group 75, Les Houches, France, October.

Strickland, J.D.H., Parsons, T.R., 1984. A Practical Handbook of Seawater Analysis, third ed. Bull. Fish. Res. Bd., Canada, 311pp.

Takahashi, T., Olafsson, J., Goddard, J.G., Chipman, D.W., Sutherland, S.C., 1993. Seasonal variation of $\mathrm{CO}_{2}$ and nutrients in the high-latitude surface oceans: a comparative study. Global Biogeochemical Cycles 7, 843-878.

Takahashi, T., Sutherland, S.C., Sweeney, C., Poisson, A., Metzl, N., Tilbrook, B., Bates, N.R., Wanninkhof, R., Feely, R.A., Sabine, C., Olafsson, J., Nojiri, Y., 2002. Global sea-air $\mathrm{CO}_{2}$ flux based on climatological surface ocean $\mathrm{pCO}_{2}$, and seasonal biological and temperature effects. Deep-Sea Research II 49, 1601-1622.

Thomas, H., Schneider, B., 1999. The seasonal cycle of carbon dioxide in Baltic Sea surface waters. Journal of Marine System 22, 53-67.

Thomas, H., Bozec, Y., Elkalay, K., de Baar, H.J.W., 2004. Enhanced open ocean storage of $\mathrm{CO}_{2}$ from shelf sea pumping. Science 304, 1005-1008.

Tseng, C.M., Wong, G.T.F., Lin, I.I., Wu, C.R., Liu, K.K., 2005. A unique seasonal pattern in phytoplankton biomass in lowlatitude waters in the South China Sea. Geophysical Research Letters 32, L08608.

Tsunogai, S., Watanabe, S., Sato, T., 1999. Is there a continental shelf pump for the absorption of atmospheric $\mathrm{CO}_{2}$. Tellus 51B, 701-712.

Wang, S.L., Chen, C.T.A., Hong, G.H., Chung, C.S., 2000. Carbon dioxide and related parameters in the East China Sea. Continental Shelf Research 20, 525-544.
Wanninkhof, R., 1992. Relationship between wind speed and gas exchange over the ocean. Journal of Geophysical Research 97, 7373-7382.

Wanninkhof, R., Thoning, K., 1993. Measurement of fugacity of $\mathrm{CO}_{2}$ in surface water using continuous and discrete sampling methods. Marine Chemistry 44, 189-204.

Weiss, R.F., 1974. Carbon dioxide in water and seawater: the solubility of a non-ideal gas. Marine Chemistry 2, 203-215.

Winn, C.D., Mackenzie, F.T., Carrillo, C.J., Sabine, C.L., Karl, D.M., 1994. Air-sea carbon dioxide exchange in the North Pacific Subtropical Gyre: implications for the global carbon budget. Global Biogeochemical Cycles 8, 157-163.

Winn, C.D., Li, Y.H., Mackenzie, F.T., Karl, D.M., 1998. Rising surface ocean dissolved inorganic carbon at the Hawaii Ocean Time-series site. Marine Chemistry 60 , 33-47.

Wong, G.T.F., Chung, S.W., Shiah, F.K., Chen, C.C., Wen, L.S., Liu, K.K., 2002. Nitrate anomaly in the upper nutrientcline in the northern South China Sea-Evidence for nitrogen fixation. Geophysical Research Letters 29.

Wong, G.T.F., Tseng, C.M., Wen, L.S., Chung, S.W., 2007. Nutrient dynamics and $\mathrm{N}$-anomaly at the SEATS station. Deep-Sea Research II, this issue [doi:10.1016/ j.dsr2.2007.05.011].

Zhai, W.D., Dai, M.H., Cai, W.J., Wang, Y.C., Hong, H.S., 2005. The partial pressure of carbon dioxide and air-sea fluxes in the northern South China Sea in spring, summer and autumn. Marine Chemistry 96, 87-97. 